\title{
Bütünleşik SWARA - MOORA Yöntemi ile Kurumsal Müşterilerin Banka Tercihlerinin Belirlenmesi: Aydın İlinde Bir Uygulama*
}

\section{Determination of Corporate Customers' Bank Preferences with Integrated SWARA - MOORA Method: An Application in the Province of Aydin}

\author{
Engin Çakır, ${ }^{\mathrm{a},{ }^{* *}}$ Elif Bilge ${ }^{\mathrm{b}}$ \\ ${ }^{a}$ Dr. Öğr. Üyesi, Aydın Adnan Menderes Üniversitesi, Nazilli İ̈BF, İşletme Bölümü, 09800, Nazilli/Aydın/Türkiye. \\ ORCID: 0000-0002-5906-4178 \\ b Bilim Uzmanı, Aydın Adnan Menderes Üniversitesi, Sosyal Bilimler Enstitüsü, İșletme Muhasebe - Finansman ABD, 09000, Aydın/Türkiye. \\ ORCID: 0000-0002-6470-6374
}

\section{MAKALE BİLGISI}

Makale Geçmişi:

Başvuru tarihi: 02 Ocak 2019

Düzeltme tarihi: 10 Temmuz 2019

Kabul tarihi: 11 Temmuz 2019

\section{Anahtar Kelimeler:}

Kurumsal Banka Müşterileri

Müşteri Beklentileri

SWARA Yöntemi

MOORA Yöntemi

\section{ARTICLE INFO}

\section{Article history:}

Received 02 January 2019

Received in revised form 10 July 2018

Accepted 11 July 2019

\section{Keywords:}

Corporate Bank Customers

Customers' Expectations

SWARA Method

MOORA Method

\section{ÖZ}

İşletme bilimi açısından bakıldığında bankacılık sektöründe ürün çıktısı hizmettir ve hizmetin müşteri nezdinde ne şekilde algılandığı önem arz etmektedir. Bu sebepten bankaların müşteri memnuniyetini göz önünde bulundurarak memnuniyetsizlik durumu oluşan hizmetlerini iyileştirmeleri gerekmektedir. Çalışmada müşterilerin bankadan beklentileri ve algılanan servis hizmetleri değerlendirme kriterleri olarak; Aydın'da faaliyet gösteren bankalar ise ele alınacak alternatifler olarak belirlenmiştir. Müşteri beklentilerinin önem dereceleri (ağırlıkları) banka müşterisi olan firma yöneticilerinin öznel değerlendirmeleri ile elde edilen veriler kullanılarak çok kriterli karar verme yöntemlerinden SWARA yöntemi ile elde edilmiştir. Daha sonra kriterlere ait önem düzeyleri de dikkate alınarak yine firma yöneticileri ile yapılan anket sonrasında elde edilen veriler yardımıyla her bir alternatif bankanın MOORA yöntemi ile değerlendirilmesi sağlanmıştır.

\section{A B S T R A C T}

Considering in terms of the business science; product output in the banking sector is service and it is important how service is perceived by customers. Therefore, it is necessary for banks to consider the customer satisfaction and enhance their services with dissatisfaction. Services expected by customers from bank and also perceived by them were determined as evaluation criteria and the banks carrying on business in Aydin were also listed as alternatives to be used in the application. Significances (weights) of customer expectations were determined with SWARA (Step-Wise Weight Assessment Ratio Analysis) method, which is among multi-criteria decision making methods, using the data acquired from the subjective evaluations of firm managers who were also bank customers. Then, each alternative bank was evaluated with MOORA (Multi Objective Optimization on basis of Ratio Analysis) method with the help of the data acquired as a result of a questionnaire that was also applied to the firm managers based on the significances of criteria.

\section{Giriş}

Bankaların kârlılığını gösteren yıllık üretim gibi geleneksel performans göstergelerinin yerini günümüzde bilgi, teknoloji, müşteri memnuniyeti, güvence gibi kriterler almıştır (Çiçek ve
Doğan, 2009: 200; Türky1lmaz ve Özkan, 2005: 73). Ölçülmesi kolay olan somut kriterler yerini ölçülmesi daha zor olan soyut kriterlere bırakmıştır. Soyut bir kavram olması sebebiyle hizmetin ölçülmesi, ürün kalitesinin ölçülmesine nazaran daha zordur. İşletmelerin rekabet edebilirliğini

* Bu çalışma, Aydın Adnan Menderes Üniversitesi Bilimsel Araştırma Projeleri Birimince desteklenmiştir. Proje Numarası: IIIBF-18002. Ayrıca bu çalışma, ikinci yazarın 2018 yılında Dr. Öğr. Üyesi Engin ÇAKIR danışmanlığında Aydın Adnan Menderes Üniversitesi Sosyal Bilimler Enstitüsü İşletme Anabilim Dalı İşletme Muhasebe - Finansman programında yürüttüğü "Kurumsal Müşterilerin Banka Tercihinde Çok Kriterli Karar Verme Yöntemleri: Aydın İlinde Bir Uygulama” başlıklı yüksek lisans tezinden türetilmiştir.

** Sorumlu yazar/Corresponding author.

e-posta: engincakir@adu.edu.tr 
etkileyen birincil yol, müşteri beklentilerine cevap verebilmektir. Müşterisini memnun edebilmiş ve bu memnuniyeti sürdürebilmiş bir işletmenin rakipleri karşısında rekabet avantajı oluşmaktadır. Çünkü beklentileri karşılanmış müşteri, diğer işletmeler yerine tekrar aynı işletmeden mal/hizmet satın alabilecektir (Çiçek ve Doğan, 2009: 200; Avcıkurt ve Köroğlu, 2006: 6). Sadık müşteriler aynı zamanda çevrelerindeki insanlara işletme ile ilgili olarak olumlu tavsiyelerde bulunacak ve kulaktan kulağa pazarlama ağı içinde işletmenin adını duyuracaktır. İşletmeler için sadık müşteri önemli bir konudur ve çalışmada "kuruma bağlılık" kriteri olarak değerlendirilmiştir. Hizmet sektöründeki bir işletmenin devamlılığı müşteri memnuniyeti ile doğrudan bağlantılıdır. Çünkü bu sektörde kalitenin tek belirleyicisi müşterilerdir (Yılmaz vd., 2007: 234).

Bankacılık sektörü, işletmeler açısından önemli bir finansman kaynağı olarak değerlendirilmektedir. Yeni fikirlerin gelişimi ve daha iyi iş firsatları için bir fon kaynağı olan bankalar, ulusal ekonominin gelişimi üzerinde de önemli rol oynamaktadır (Güneysu vd., 2015: 72). Banka müşterisi konumundaki işletmeler, çalıştıkları bankalar hakkında bilgi sahibi olmak isterler. Dolayısıyla bir analiz yöntemi olarak ÇKKV (Çok Kriterli Karar Verme) yöntemleri bankaların değerlendirilmesinde uygulanabilmektedir (Akçakanat vd., 2017: 286).

Müşterilerin banka tercihini etkileyen kriterler ve bunların değerlendirilmesi bu çalışmanın konusunu oluşturmaktadır. Müşteri beklentilerinin önem dereceleri (ağırlıkları) banka müşterisi olan firma yöneticilerinin öznel değerlendirmeleri ile elde edilen veriler kullanılarak ÇKKV yöntemlerinden SWARA (Step-Wise Weight Assessment Ratio Analysis Adım Adım Ağırlık Değerlendirme Oran Analizi) yöntemi ile elde edilmiştir. Daha sonra kriterlere ait önem dereceleri de dikkate alınarak yine firma yöneticileri ile yapılan anket sonrasında elde edilen veriler yardımıyla her bir alternatif bankanın MOORA (Multi Objective Optimization on basis of Ratio Analysis - Oran Analizi Bazında Çok Amaçlı Optimizasyon Yöntemi) yöntemi ile değerlendirilmesi sağlanmıştır.

Çalışmanın amacı, kurumsal banka müşterilerinin banka tercihinde etkili olan kriterlerin (teknoloji, işlem kolaylığı ve maliyeti, ürün ve hizmet çeşitliliği, güvenilirlik, erişim, imaj1/itibar, kuruma bağl1lık vb.) SWARA yöntemi ile önem derecelerinin belirlenmesi ve alternatif bankaların MOORA yöntemi ile değerlendirilmesidir.

Çalışmanın önemi, mevcut yazında banka tercihinde çoğunlukla performans değerlemede somut sayısal verilerden yararlanılmıştır. Bu çalışmada daha güncel ve müşteri odaklı sonuçlar getireceğine inanılan öznel verilerden yararlanılmıştır. Öncelikle kurumsal müşterilerin banka tercihinde etkili olması muhtemel tüm kriterler literatür dikkate alınarak belirlenmiştir. Sonrasında Aydın ilinde kurumsal banka müşterisi olan işletme yöneticilerine iki aşamalı anket uygulanmıştır. Toplamda 10 kurumsal banka müşterisi ile birebir görüşme sağlanarak, öncelikle kriterleri, daha sonra da alternatif bankaları değerlendirmeleri istenmiştir. Elde edilen verilerin, bütünleşik SWARA MOORA yöntemi ile değerlendirmesi yapılmış ve en yüksek öneme sahip kriterler ile kurumsal bankacılık konusunda hangi bankanın daha yüksek skorlara sahip olduğu belirlenmiştir.

\section{Literatür Taraması}

\subsection{Banka Tercihlerindeki Kriterler Üzerine Literatür} Taramas1

$\mathrm{Bu}$ çalışmada amaçlanan Aydın ilinde faaliyet gösteren bankaların kurumsal banka müşterileri nezdinde değerlendirilmesidir. Bankaların tercih edilmesi noktasında bireysel ya da kurumsal banka müşterilerinin göz önünde bulundurdukları kriterler literatürde incelenmiş ve aşağıda bu konuda yapılan bazı çalışmalara yer verilmiştir:

Kaynak vd. (1991) tarafından Eskişehir ili merkez ilçesinde yapılan çalışmada 250 kişiye yüz yüze görüşme yoluyla anketler doldurtulmuş ve anket sonuçları istatistiksel biçimde faktör analizi, ANOVA ve t-testi uygulanarak değerlendirilmiştir. Çalışmada, "bankanın tanınmışlığı ve imajı", "bankanın çalışma saatleri”, "bankanın otopark hizmeti", "banka tarafından sunulan hizmetlerinin çeşitliliğì", "bankanın arkadaş ve akrabalarca tavsiye edilmesi", "bankanın hizlı ve etkin hizmet sunumu", "bankanın elektrik faturası ödeyebilme olanağı sunması", "bankanın finansal danışmanlık hizmeti sağlaması” seçeneklerini erkekler kadınlara oranla daha çok önemsemektedirler. Aynı çalışma, banka hizmetlerinden sik faydalananların banka hizmetlerinden sık faydalanmayanlara oranla "banka çalışanlarının dostça davranışlarını", "bankanın eve ya da işe yakın olmasını", "hızlı ve etkin hizmet sunumunu", "kredi olanağının bulunmasını" ve "finansal danışmanlık hizmeti sağlanmasını" daha çok önemsemektedirler.

Khazeh ve Decker (1992)'in Amerika Birleşik Devletleri'nin Maryland Eyaleti'nde yaptıkları çalışmada tüketicilerin bankaları tercih etme nedenleri arasında öne çıkan kriterler arasında "ücret ve komisyonlar", "bankanın itibarı", "kredi faiz oranları", "kredi taleplerinin hızlı sonuçlandırılması" ve "banka personelinin samimi davranışları" olarak bulunmuştur.

Çınar ve Erciş (1993) tarafından Erzurum ili merkez ilçesinde, genç nüfus üzerine yapılan çalışmanın analiz edilmesi sonucunda Erzurum ili merkez ilçesinde yaşayan genç nüfusun banka tercihinde etkili olan en önemli kriterin "bankaların yaptığı işlemlerden masraf almaması" olduğu tespit edilmiştir. Bunun yanında, "bankanın yaygın hizmet sunması", "bankanın devlet bankası olması", "bankanın verdiği faizin yüksek olması", "bankanın ATM kartı vermesi”, "bankanın kredi kartı vermesi”, "bankanın vadesiz mevduatlara yüksek faiz vermesi", "bankanın çek defteri vermesi", "bankanın tüketici, otomobil, eşya, ev kredisi vermesi" takip etmiştir.

Boyd vd. (1994) tarafindan Amerika Birleşik Devletleri’nde tüketicilerin finansal hizmet sunan kurumları tercih etmede dikkate aldıkları kriterleri belirlemek üzere yapılan çalışmada "kurumun tanınmışlığgl", "mevduat faiz oranları", "kredi faizleri oranları", "hızlı hizmet sunumu", "uygun yerleşim yeri”, "çalışma saatleri”, "kurumda tüketicinin hesabının bulunması", "çalışanların dostça yaklaşımı", "modern teknolojik olanaklar" ve "müşterilerine araba içinde servis yapan banka (drive-in service)" kriterleri önem derecelerine göre sıralanmıştır.

Yue ve Tom (1995)'un Çin Halk Cumhuriyeti'nde yaptıkları araştırmada tüketicilerin banka tercih sebepleri arasında en yüksek değerlere sahip kriterler uluslararası şube ağının varlığı ve genişliği ile hizmet kalitesidir. 
Zineldin (1996) tarafından İsveç'te yapılan çalışmanın sonuçlarına göre tüketicilerin banka tercihine etki eden kriterler arasında "banka personelinin yardımsever ve dostça davranması", "doğru portföy yönetimi", "hatalı işlemlerin hızlı olarak çözümlenmesi", "kolay kredi temini", "süratli hizmet ve işlemlerin çabuk sonuçlandırılması", "rekabetçi fiyat" ve "çalışma saatleri" gibi kriterler öne çıkmaktadır.

Kennington vd. (1996) tarafindan Polonya'da yapılan araştırmada tüketicilerin banka tercihinde "bankanın imajını", "bankanın uyguladığı ücretleri, faiz ve diğer masraflarını", "bankanın sunmuş olduğu hizmetlerdeki işlem kolaylığını", "sunulan hizmetin kalitesini", "aile ve arkadaş çevresinin önerilerini", "mevduata uygulanan devlet garantisini" ve "bankanın devlet bankası olmasını" dikkate aldıkları belirtilmektedir.

Almahmeed ve Thabet (1997)'in Kuveyt'te yaptıkları araştırmada "bankanın aktif büyüklügünün”, "personelin etkinliğinin", "finansal ihtiyaçların giderilmesinde sağlanan yardımın", "uzman bankacılık hizmetinin", "personelin sıcakkanlı ve dostça davranışlarının", "bankanın itibarının" ve "personel ile kurulan iletişimin" tüketicilerin banka tercihine etki eden faktörler arasında öne çıktığı görülmüştür.

Nielson vd. (1998) Avustralya'da örgütsel tüketicilerin banka tercihlerinde etkili olan nedenler ile ilgili yaptıkları çalışmada "bankanın uzun dönem ilişki kurabilme yeterliliğii", "bankanın kredi ihtiyaçlarına cevap verebilmesi, "rekabetçi ücret ve komisyonlar", "günlük işlemlerindeki etkinliği", "müşteri ilişkileri" ve "uygun yerleşim yeri" en önemli kriterler olarak tespit edilmiştir.

Metawa ve Almossawi (1998)'nin Bahreyn'de yaptıkları araştırmanın sonuçlarına göre tüketicilerin İslam bankalarını seçmelerinde etkili olan kriterler önem derecesine göre "İslam ilkelerine uygunluk", "getiri oranı", "aile ve arkadaş tavsiyesi" ve “uygun yerleşim yeri”" şeklinde sıralanmıştır.

Owusu-Frimpong (1999) tarafindan Gana'da yapılan bir çalışmada tüketicilerin banka hesabı açarken dikkate aldıkları kriterler; "yüksek faiz oranı", "çalışanların anlayışı”, "etkin hizmet sunumu", "banka hesabı açmanın riski düşük yatırım olması", "anında nakit hizmeti sunulması", "bankanın geniş hizmet yelpazesinin bulunması", "banka tarafından düzenli hesap özeti gönderilmesi”, "bankanın toplumsal konularda duyarlılık göstermesi" ve "kişisel hizmet sunumu" olarak sıralanmıştır. Aynı çalışmada tüketiciler, bankanın imajını ve tanınmışlığını etkileyen kriterleri; bankanın yerleşim yerinin uygun olması, çalışanların dostça davranması, bankanın büyüklüğü, kar odaklı olması, hizmette çabukluk, kolay kredi alabilme, çalışanların nezaketi, toplumsal olaylara duyarlılık gösterilmesi şeklinde sıralamıştır.

Almossawi (2001) tarafindan Bahreyn'de genç nüfusun bankaları tercih etme nedenlerini belirlemek üzere yapılan bir araştırmada en yüksek değerleri alan kriterler “ATM'lerin uygun yerde bulunması”, "ATM'lerin birçok yerde ve işlem yapılabilir durumda olması", "bankanın itibarı", "ATM'lerin 24 saat hizmet verebilmesi" ve "bankaya yakın yerlerde otomobil park yerlerinin bulunması" şeklinde sıralanmıştır.

Wel ve Nor (2003) tarafindan Malezya'da yapılan bir çalışmada tüketicilerin bankaları tercih etmesinde "kişisel" ve "sosyolojik" olmak üzere iki unsurun ön planda olduğu gözlenmiştir. Kişisel kriterler arasında, "farklı şubelerde para yatırma- çekme işlemlerinin kolaylığı", "alışveriş merkezlerinde ATM'lerinin bulunması", "bankanın finansal gücü”, "fon güvenliği”, "bireysel ihtiyaçların karşılanabilmesi”, "düzenli ekstre bildirimi”, "tüm bankacılık hizmetlerinin sunulması", "banka şubesinin iş yerlerine ve evlere yakın olması" ve "banka şubesinin toplu taşıtlara yakınlığı ön plana çıkarken; sosyolojik kriterler arasında, "bankanın itibarı", "ismi”, "banka hizmetlerinin etkin olduğu konusundaki duyumlar", "banka yöneticilerinin kalitesi", "bankanın toplumsal konulara hassasiyeti", "akrabaların tavsiyesi”, "arkadaşların tavsiyesi", "ailenin geleneksel olarak aynı banka ile çalışması" ve "akraba veya iş arkadaşlarının bankada çalışması” ön plana çıkmaktadır. Aynı çalışmada yapılan karşılaştırma sonucunda, kişisel kriterlerin sosyolojik kriterlere göre banka tercihinde daha etkili olduğu gözlenmiştir.

Lam ve Burton (2005) tarafindan Hong Kong'da yapılan araştırmada örgütsel tüketicilerin banka tercihinde etkili olabilecek kriterler belirlenmiştir. $\mathrm{Bu}$ kriterler arasında; "bankanın kredi ihtiyaçlarına cevap verebilmesi", "bankanın iyi müşteri ilişkileri ve bağlantıları", "bankanın yerleşim yerinin uygun olması", "banka personelinin hizmet sunumu", "bankanın günlük işlemlerindeki etkinliği" ve "bankanın ürünhizmet yapısındaki esneklik" yer almaktadır.

Devlin ve Gerrard (2005)'in birden çok bankadan hizmet alan müşterilerin banka tercihlerini ve banka tercih sıralamalarını etkileyen kriterlerin belirlenmesine yönelik yaptıkları araştırmaya göre, müşterilerinin ana bankası ve ikincil bankalarının seçimi konusunda farkların olduğunu, banka tercihini etkileyen temel kriterlerin "hizmet kalitesi” ve "düşük faizli kredi verme" olduğunu tespit etmişlerdir.

Bei ve Shang (2006) tarafindan Tayvan'da kamu ve özel bankaların müşterileri karşılaştırmalı olarak inceledikleri araştırmada, kamu bankası müşterilerinin memnuniyet dereceleri daha düşük bulunmuştur.

Lariviere ve Poel (2007) çalışmalarında banka müşterisi konumundaki öğrencilerin oluşturduğu pazarı incelemişlerdir. Bu çalışmada, banka hizmetlerinin öğrenci pazarına sunulması ve öğrencilere yapılan pazarlama yatırımları ile öğrencilik dönemi sonrasında da aynı grubun banka tercihi arasındaki ilişki incelenmiştir. Çalışmanın sonucunda, bankaların öğrencilere yaptıkları pazarlama yatırımlarının, öğrencilik sonrasındaki banka tercihlerini olumlu etkilediği tespit edilmiştir.

Mokhlis (2009) Malezya'da ticari banka seçimi ile ilgili yaptıkları çalışmada; yalnızca tek banka kullanan müşterilerle çok sayıda banka kullanan müşterileri kıyaslamışlar ve sonuç olarak, bankanın çekiciliği, ATM hizmeti, şubenin konumu, finansal avantajlar ve güvenlik kriterleri açısından bu iki grup arasında farklılıkların olduğu görülmüştür. Çok sayıda bankanın müşterisi olanların bu belirtilen tüm faktörlere daha fazla önem verdikleri belirlenmiştir.

Taşkın vd. (2010)'nin tüketicilerin banka tercihlerinde etkili olan kriterlerin belirlenmesi ve bankaların pazarlama stratejilerinde yararlı olabilecek bilgilere ulaşmak amacıyla Bursa'da yaptıkları araştırma sonucunda müşterilerin banka tercihinde etkili olan en önemli kriterleri sırasıyla; "güvenilirlik", "reklam", "sosyal ve teknik yeterlilik", "fiziksel görünüm" ve "banka hizmetlerine ulaşılabilirlik" olduğunu belirlemişlerdir. 
Awan ve Bukhari (2011) Pakistan'da müsțterilerin İslami banka seçimini etkileyen kriterleri incelemiş; banka tercihinde müşteriler tarafından en fazla önem verilen kriterlerin "ürün özellikleri” ve "hizmet kalitesi” olduğunu, "dini inançların" ise daha az önemli faktör olarak geri planda kaldığı görülmüştür.

Chigamba ve Fatoki (2011) tarafından, Güney Afrika'da yapılan çalışmada üniversite öğrencilerinin ticari banka seçiminde "hizmet", "yakınlık", "çekicilik", "tavsiyeler", "pazarlama" ve "fiyat" kriterlerinin belirleyici olduğu tespit edilmiştir. Öğrencilerin banka seçiminde ilk sırada "bankanın sunduğu hizmet kalitesi" yerini alırken bunu, "bankanın lokasyonu" izlemektedir.

Özsoy vd. (2013)'nin Bolu ilinde, katılım bankalarının tercih edilme sebeplerini belirlemek üzere yaptıkları çalışmada faktör analizi yapılmış; "Hizmet/ürün kalitesi" kriterinin katılımcıların katılım bankasını tercih etmesinde en önemli kriter olduğunu ve bunu, sırasıyla "imaj ve güven", "personel kalitesi" ve "dini ve çevresel motivasyonlar" kriterlerinin izlediğini belirlemişlerdir.

Cebeci ve Çabuk (2016) Giresun ili Görele ilçesindeki banka müşterilerinin banka tercihlerini etkileyen kriterleri tespit etmek ve önem dereceleri ortaya koymak amacıyla yaptıkları çalışmada; anket yöntemi ile veriler toplanıp açıklayıcı faktör analizi sonucu ölçeğin yedi faktörlü yapıda olduğu belirlenmiştir. Belirlenen bu 7 faktörün varyansa yaptığı katkı sırasıyla; "şube ve alternatif kanal ağı", "personel özellikleri”, "işlem kolaylığı ve maliyeti", "bankanın fiziki ve teknik yapısı", "ürün ve hizmet çeşitliği”, "bankanın güvenilirliği”, "hız" olduğu tespit edilmiştir.

\subsection{Bankaların Değerlendirilmesinde Kullanılan ÇKKV Yöntemleri Üzerine Literatür Taraması}

Literatürde bankacılık sektöründe ÇKKV yöntemlerini kullanan çalışmalar incelenmiştir. Aşağıda ÇKKV yöntemlerinin bankacılık sektörü üzerinde uygulandığı bazı çalışmalara yer verilmiştir.

Blien ve Tassinopoulos (2001) istihdam tahmini yapmışlar ve çalışma, Federal İşsizlik Hizmetleri’nin bütçe planlamasında yararlı olmuştur. $\mathrm{Bu}$ çalışmayla birlikte işgücü piyasası fonlarının ülke dağılımında iyileştirme yapılmasının mümkün olabileceği görülmüştür.

Albayrak ve Erkut (2005) finansal ve finansal olmayan kriterlerin bir arada kullanıldığı çok amaçlı bir performans değerlendirme modeli kurarak, banka performanslarının değerlendirmeye çalışmışlardır. Bu gayeyle Analitik Hiyerarşi Süreci (AHP) yöntemine göre oluşturulan ve Analitik Hiyerarşi Performans Modeli (AHPM) olarak adlandırılan, yapısında karlılık ve risk kriterleri gibi finansal kriterler ve hizmet kalitesi ve müşteri memnuniyeti gibi finansal olmayan kriterlerinin birlikte kullanılmasına olanak tanıyan bir model önerilmiştir. Çalışmada, banka sektöründe, yalnızca finansal kriterlerle yapılan performans değerlendirmesinin, sosyal kriterler göz önüne alınmadan eksik sonuçlar vereceği kanıtlanmaya çalışılmıştır.

Kılıç (2006) çalışmasında ilk olarak finansal başarısızlığın yaşanmasından bir yıl öncesi için, başarısız olan ve faaliyetini devam ettiren bankaları birbirinden ayırt eden 10 oran "erken uyarı göstergesi” olarak saptanmıştır. Sonrasında, bu oranlar ÇKKV yöntemlerinden biri olan ELECTRE TRI modelinde kriter olarak kullanılmış ve bu modele göre bankalar sınıflandırılmıştır. Çalışmanın sonuçları göstermektedir ki, tahmin edilen erken uyarı sisteminin uygulanması ile finansal başarısızlığın sonucu olarak gerçekleşen yeniden yapılandırma maliyetlerinden büyük oranda kaçınmak mümkündür.

Coşkun (2006), banka performansının değerlendirilmesinde finansal kriterlerin yanı sira finansal olmayan kriterleri de dikkate alabilen performans karnesi yöntemini ele almıştır. Çalışmada performans karnesi kavramı açıklanmış ve bankalardaki uygulama örnekleri incelenmiştir.

Ravi vd. (2008) bankaların performans tahmininde finansal oranlardan yararlanılan bir yaklaşım önermiştir. Bu yaklaşım, ele alınan bankalar için geçmiş iki yılın verileri kullanılarak gelecek yılın performansinın tahmin edilmesine dayanmaktadir.

Bergendahl ve Lindblom (2008), "İsveç Tasarruf Bankalarının Hizmet Verimliliğine Göre Performansının Değerlendirilmesi” adlı çalışmalarında Veri Zarflama Analizi (VZA) kullanarak İsveç yatırım bankalarının performanslarını değerlendirmişlerdir.

Kosmidou ve Zopounidis (2008), 2003 ve 2004 y1lları arasında Yunanistan'daki ticari ve kooperatif bankaların performanslarını PROMETHEE yöntemini kullanarak değerlendirmişlerdir. Çalışmadan elde edilen sonuçlara göre, ticari bankalar kazançlarını üst düzeye çıkarmak için daha fazla müşteri çekmeli, hesaplarını arttırmalı ve mali endekslerini iyileştirmelilerdir. Kooperatif bankalarda ise sonuçlar değişkenlik göstermiştir. Çünkü piyasa paylarında artışa sahip olan bankalar ve bunun haricinde mali göstergeleri kötüleşen bankalar vardır.

Ertuğrul ve Karakaşoğlu (2009)'nun "Banka Şube Performanslarının VIKOR Yöntemiyle Değerlendirilmesi” adlı çalışmalarında, ÇKKV yöntemlerinden biri olan VIKOR yöntemi kullanılarak bir bankanın şubelerinin performansları değerlendirilmiş ve şubeler arasında performansa göre bir sıralama yapılmışlardır. $\mathrm{Bu}$ yöntem alternatifler arasında bir sıralama belirlemeye ve belirtilen ağırlıklar altında uzlaşık bir çözüme ulaşmaya dayanmaktadır.

Wu vd. (2009) çalışmalarında, Bulanık ÇKKV Yöntemleri ile bankaların performanslarını incelemişlerdir. Çalışmada yirmi üç alternatif ve üç kriter kullanılmış ve uzman görüşleri alınarak bulanık AHP yöntemi ile kriterin ağırlıkları hesaplanmıştır. Sonrasında sırasıyla SAW, TOPSIS ve VIKOR yöntemleri uygulanmıştır. Çalışmanın sonucunda bulanık ÇKKV yöntemlerinin banka performanslarının değerlendirilmesinde uygun ve kullanışlı olduğu görülmüştür.

Demireli (2010)'nin “TOPSIS Çok Kriterli Karar Verme Sistemi: Türkiye'deki Kamu Bankaları Üzerine Bir Uygulama" adlı çalışmasında bankalarının performanslarını ÇKKV yöntemlerinden biri olan TOPSIS yöntemi ile belirlenmeyi amaçlamıştır. Bu amaçla literatürde en fazla kullanılan kriterler çalışmaya dahil edilerek bunlara eşit ağırlıklar verilmiş böylece performans puanları elde edilmiştir. Çalışma sonucunda yurt içinde yaygın olarak faaliyette bulunan kamu bankalarının finansal krizlerden etkilendiği, performans puanlarının yurtdışı verilere dayalı olarak sürekli dalgalanmalar gösterdiği, bankacılık sektöründe göze çarpan bir iyileşmenin kaydedilemediği saptanmıştır. 
Doumpos ve Zopounidis (2010)'in çalışmalarında, ÇKKV yöntemleri ile bankaların sıralamasını yapmışlardır. 31 kriterin kullanıldığı çalışmada PROMETHEE II yöntemini kullanmışlardır. Çalışmada sonuçların değerlendirme parametrelerine olan duyarlılı̆̆ına vurgu yapılmış ve bu da bankaların güçlü ve zayıf yönleri üzerinde faydalı sonuçlar verdiğini göstermiştir.

Çağıl (2011), çalışmasında 2006 - 2010 dönemlerine ait mevduat bankaları ile Türkiye'de kurulan yabancı sermayeli bankalar üzerinde ELECTRE yöntemini kullanarak finansal performans analizinin yapılmasını hedeflemiş̧ir. Bankaların performans sıralamaları incelendiğinde kriz dönemlerinde bazı bankalarda sıralama sapması yaşandığı sonucuna ulaşılmıştır.

Dinçer ve Görener (2011) çalışmalarında Türkiye'deki kamu, özel ve yabancı sermayeli bankaları gruplandırmışlar, bu grupların kriter ağırlıklarını AHP yardımıyla hesaplamış, daha sonra VIKOR yöntemiyle performans ölçümü gerçekleştirmişlerdir. Çalışmada, 2002- 2008 yıllarını kapsayan dönemlerde bu üç banka grubunun performanslarının analiz edilmesi amaçlanmıştır. Sonuçlar incelendiğinde en iyi performansı gösteren bankaların; 2002, 2003 ve 2008 yıllarında yabancı sermayeli bankalar, 20042007 yılları arasında ise kamu bankaları olduğu görülmektedir.

Sakarya ve Aytekin (2013) çalışmalarında, İMKB'de işlem gören kamusal, özel ve yabancı sermayeli mevduat bankalarının on finansal oran seçilerek PROMETHEE yöntemiyle 2007- 2011 arası döneme ait finansal performanslarının ve hisse senedi getirileri ile elde edilen performans sonuçları arasındaki ilişkinin ölçülmesini amaçlamışlardır.

Yayar ve Baykara (2012)'nın, "TOPSIS Yöntemi ile Katılım Bankalarının Etkinliği ve Verimliliği Üzerine Bir Uygulama" adlı çalışmalarında, katılım bankalarının 2005- 2011 yıllarındaki faaliyetlerinin verimliliklerini ve etkinliklerini TOPSIS yöntemini kullanarak ölçmeye çalışmışlardır.

Amile vd. (2013) çalışmalarında uzman görüşlerinden yararlanı finansal ve finansal olmayan kriterler kullanmışlardır. Beş finansal, sekiz finansal olmayan kriter kullanılarak öncelikle bulanık AHP yöntemi ile kriterler ağırlıklandırılmış sonrasında TOPSIS yöntemi ile bankaların sıralanmıştır.

Ecer (2013) “Türkiye'deki Özel Bankaların Finansal Performanslarının Karşılaştırılması: 2008-2011 Dönemi” adlı çalışmasında Gri İlişkisel Analiz (GİA) yöntemini kullanarak 2008- 2011 döneminde özel Türk bankaların finansal performanslarını karşılaştırmıştır. Bu amaçla 11 özel banka CAMELS kriterlerinden sermaye yeterliliği, likidite, aktif kalitesi ve karlılık göstergeleri kapsamında yer alan 12 finansal rasyo kullanılarak performanslarına göre sıralanmıştır. Elde edilen sonuçlara göre Garanti Bankası ilk sırada yer alırken Turkish Bank son sırada yer almıştır.

Bağcı ve Rençber (2014) çalışmalarında, kamu bankaları ve özel bankalar arasındaki kârlılıklarının karşılaştırmasını incelemişlerdir. PROMETHEE yöntemi ile yapılan çalışmada, analizler için üç kamu bankası ve halka açık on özel banka kullanılmıştır. 2006- 2012 yılları arasını kapsayan çalışmanın sonucunda, kamu bankaları içerisinde en kârlı bankanın Halk Bankası, özel bankalar içerisinde ise Denizbank olduğu sonucuna ulaşılmıştır. Tüm bankalar incelendiğinde ise; hem kamu bankalarının daha kârlı olduğu hem de Halk Bankası'nın en kârlı banka olduğu çalışmanın sonucuna görülmektedir.

Güneysu vd. (2015) çalışmalarında, ticari bankaların 20102014 yillarındaki finansal performanslarını, 16 adet finansal rasyo yardımıyla ÇKKV yöntemlerini ile değerlendirmiştir. Çalışmada AHP ve Gri İliş̧kisel Analiz (GIA) yöntemleri kullanılmıştır. Elde edilen sonuçlara göre en iyi performansa sahip bankaların, kamu sermayeli bankalardan Ziraat Bankası, özel sermayeli bankalardan Adabank ve yabancı sermayeli bankalardan ise JP Morgan Chase Bank olduğu ortaya koyulmuştur.

Taşabat vd. (2015) çalışmalarında, Türk Bankacılık Sektöründe faaliyet gösteren mevduat bankalarının 2013 yılındaki mali performanslarını değerlendirmişlerdir. Çalışmada ÇKKV yöntemlerinden ELECTRE, TOPSIS, VIKOR, PROMETHEE, ORESTE, MAPPAC ve WSA'nın “eşit ağırlık, puanlama ve Saaty'nin yöntemi” olarak bilinen ağırlıklandırma tekniklerini kullanmışlardır. Analizler sonucunda bankalar arasında derecelendirmeye gidilerek ÇKKV yöntemlerinin probleme uygunluğu incelenmiş ve kullanılan kriter ağırlıklandırma tekniklerinin önemi vurgulanmıştır.

Çalışkan ve Eren (2016) çalışmalarında, 2010-2014 yılları arasında verisi olan ilk yirmi kamusal, özel ve yabancı sermayeli mevduat bankalarının on adet finansal oran yardımıla ÇKKV yöntemlerinden AHP ve PROMETHEE kullanarak finansal performanslarının karşılaştırılmasını amaçlamışlardır.

Kandemir ve Karataş (2016) çalışmalarında, BİST'de işlem gören 12 mevduat bankasının 2004- 2014 yıllarındaki finansal performansları incelenmiştir. Çalışmada ÇKKV yöntemlerinden Gri ilişkisel analiz, TOPSIS ve VIKOR yöntemleri kullanılmıştır. Çalışmadan elde edilen sonuca göre; Gri İlişkisel Analiz yönteminde, en yüksek finansal performansa sahip bankanın Vakıfbank, en düşük finansal performansa sahip bankanın ise Şekerbank olduğu tespit edilmiştir.

Tezergil (2016) çalışmasında, Türk bankacılık sektöründe faaliyet gösteren mevduat bankalarının finansal performanslarının değerlendirilmesini amaçlamıştır. Çalışmada 2009-2013 yıllarında Türkiye'deki 28 mevduat bankasına ait mali tablolardan elde edilen finansal oranlardan yararlanılarak VIKOR yöntemi ile performans siralamaları yapılmıştır.

Akçakanat vd. (2017) çalışmalarında aktif büyüklüklerine göre küçük, orta ve büyük ölçekli bankaların performanslarını ÇKKV yöntemlerinden ENTROPI ve WASPAS ile değerlendirmeyi amaçlamışlardır. Çalışmada toplam aktifler, toplam krediler ve alacaklar, toplam mevduat, toplam öz kaynaklar, şube sayısı ve personel sayısı kriterler olarak belirlenmiştir. Kriter ağırlıklarının ENTROPİ yöntemi ile hesaplanıp WASPAS yöntemiyle değerlendirme yapılmıştır. Çalışmanın sonucuna göre en iyi performans gösteren bankalar olarak büyük ölçekli bankalar arasında Ziraat Bankası, orta ölçekli bankalar arasında Finans Bank, küçük ölçekli bankalar arasında ise Anadolu Bank olduğu tespit edilmiştir. 


\section{3. Çalışmanın Yöntemi ve ÇKKV Yöntemleri}

İnsanlar yaşamları boyunca birçok konuda kararlar vermektedir. Bu kararlar belirli kriterlere sahip olup kriterlerin ağırlıkları kişiden kişiye değişiklik gösterebilmektedir. Örneğin; otomobil satın alma kararında da kimine göre marka, kimine göre fiyat, kimine göre dayanıklılık ya da yakıt daha önemli olabilir. Benzer durum işletmelerde de geçerlidir. Bu sebeple kişiler veya işletmeler karar verirken alternatiflerin değerlendirilmesinde ÇKKV yöntemlerini kullanabilirler. ÇKKV yöntemleri, mevcut alternatifleri kriter ağırlıklarına göre değerlendirerek, en iyi çözüme ulaşır. ÇKKV yöntemlerinin sayesinde karar verici; eldeki alternatifleri sıralayabilir, sınıflandırabilir veya aralarından seçim yapabilir (Genç ve Masca, 2013: 540; Ömürbek vd., 2014: 48).

ÇKKV; somut ve soyut kriterlere (niteliklere) göre potansiyel karar seçenekleri arasından en iyinin seçimi ile ilgilenmektedir (Cho, 2003: 1099; Ömürbek ve Aksoy, 2016: 725).

Bu çalışmada ÇKKV yöntemlerinden SWARA yöntemi ile kriterler ağırlıklandırılmış, MOORA yöntemi ile alternatiflerin değerlendirilmesi sağlanmıştır.

\subsection{SWARA Yöntemi}

Türkçe karşılığg “Adım Adım Ağırlık Değerlendirme Oran Analizi” olarak adlandırılabilen SWARA yöntemi Keršuliene, Zavadskas ve Turskis tarafindan 2010 yılında önerilmiş ve geliştirilmiştir (Özbek, 2017: 43; Yurdoğlu ve Kundakc1, 2017: 258; Çakır, 2016: 45).

SWARA yöntemi kullanılarak kriterlerin göreceli ağırlıkları belirlenebilmektedir (Stanujkic vd., 2015: 182; Özbek, 2017: 46). Yöntemde ilk olarak alternatiflerin değerlendirilmesinde kullanılacak olan kriterler en önemliden önemsize doğru sıralanmaktadır. Birden fazla karar vericinin katıldığı bu süreçte; sıralamada birinci sırada en önemli kriter bulunurken son sırada en az önemli kriter yer alır (Keršuliene vd., 2010: 249; Zolfani vd., 2013: 158; Yurdoğlu ve Kundakc1, 2017: 258). Nihai ağırlıklandırma, karar vericilerin belirledikleri önem düzeylerinin geometrik ortalaması ile belirlenir (Zolfani vd., 2013: 158; Özbek, 2017: 43; Çakır, 2016: 49; Çakır ve Akar, 2017: 212).

SWARA yönteminin işlem adımları aşağıdaki gibi özetlenebilir:

1. Adım: Kriterler, karar vericinin görüşü doğrultusunda önem sırasına göre azalan düzende sıralanır (Özbek, 2017: 46).

2. Adım: İkinci kriterden başlamak suretiyle, her kriter için göreceli önem düzeyi belirlenir (Çakır ve Akar, 2017: 209). Bunun için her kriter $(j)$ bir önceki kriter $(j-1)$ ile karşılaştırılarak (j-1) kriterinin j kriterinden ne kadar önemli olduğu belirlenir (Ruzgyz vd., 2014: 107; Yurdoğlu ve Kundakc1, 2017: 258). Bu değer Keršulienè vd. (2010: 253) tarafından "ortalama değerin karşılaştırmalı önemi" şeklinde adlandırılmış ve " $s_{j}$ " ile gösterilmiştir (Özbek, 2017: 46; Çakır ve Akar, 2017: 209).

3. Adım: Tüm kriterler için katsayı değeri $k_{j}$, Eşitlik (1) kullanılarak hesaplanır. En büyük $s_{j}$ değerine sahip kritere ait katsayı $k_{j}=1$ değerini almaktadır (Yurdoğlu ve Kundakc1, 2017: 258). $k_{j}$ katsayısı Eşitlik (1) ile belirlenir: $k_{j}= \begin{cases}1 & j=1 \\ s_{j}+1 & j>1\end{cases}$

4. Adım: Tüm kriterler için düzeltilmiş ağırlıklar $\left(q_{j}\right)$, Eşitlik (2) yardımıyla hesaplanır. Birinci sırada yer alan kriterin düzeltilmiş ağırlığı $q_{j}=1$ 'dir (Yurdoğlu ve Kundakc1, 2017: 258). Önem vektörü $q_{j}$ Eşitlik (2) ile hesaplanır:

$q_{j}=\left\{\begin{array}{cc}1 & j=1 \\ \frac{X_{j-1}}{k_{j}} & j>1\end{array}\right.$

5. Adım: Kriterlerin göreceli ağırlıkları $\left(w_{j}\right)$ Eşitlik (3) yardımıyla hesaplanır. $w_{j}$ simgesi, $j$. kriterin göreceli ağırlığını göstermektedir.

$$
w_{j}=\frac{q_{j}}{\sum_{k=1}^{n} q_{k}}
$$

\subsection{MOORA Yöntemi}

Çok sayıdaki alternatif arasından karar vermeye yardımcı olmak amaciyla ÇKKV yöntemleri geliştirilmiştir. MOORA yöntemi de bu ÇKKV yöntemlerinden biridir (Özcan ve Ömürbek, 2016: 67). MOORA yöntemi Willem Karel M. Brauers ve Edmundas Kazimieras Zavadskas tarafindan 2006 y1lında tanıtılmıştır (Özbek, 2017: 183). Yöntem, farklı öngörülerin gruplandırılmasına dayanmaktadır (Brauers ve Zavadskas, 2006: 447). MOORA yöntemi; farklı alternatiflerin farklı kriterlere karşılık gelmesi ile oluşan matrisin hazırlanması ile başlamaktadır (Karaca, 2011: 23-24). Matris " $x_{i j}$ " şeklinde gösterilmekte ve bu ifade, $j$. kriterinin $i$. alternatife yanıtı olarak tanımlanmaktadır (Brauners ve Ginevicius, 2009: 123).

Oran analizine dayanan MOORA yönteminde farklı teknikler ve yaklaşımlar bulunmaktadır. Bunlar:

- MOORA-Oran metodu,

- MOORA-Referans nokta yaklaşımı,

- MOORA-Tam çarpım formu,

- MOORA-Önem katsayısı,

- MULTI-MOORA.

1. Adım: Yöntem matris şeklinde verilerin yazılmasıyla başlar (Brauers ve Zavadskas, 2006: 447; Yıldırım ve Önder, 2015: 246). Karar matrisinin satırlarına üstünlükleri sıralanacak alternatifler, sütunlarına ise değerlendirme kriterleri yazılmaktadır (Özcan ve Ömürbek, 2016: 68). Karar matrisi aşağıdaki gibidir (4);

$$
X_{i j}=\left[\begin{array}{cccc}
x_{11} & x_{12} & \cdots & x_{1 n} \\
x_{21} & x_{22} & \cdots & x_{2 n} \\
\vdots & \vdots & \ddots & \vdots \\
x_{m 1} & x_{m 2} & \ldots & x_{m n}
\end{array}\right] \quad j=1,2, \ldots, m \text { (alternatifler) }
$$

2. Adım: $i=1,2, \ldots, m$ alternatifin sayıs $, j=1,2, \ldots, n$ kriter sayısı olmak üzere, her bir alternatifin karelerinin toplamının karekökü ile kriterler bölünerek normalizasyon işlemi yapılır (Y1ldırım ve Önder, 2015: 246; Özcan ve Ömürbek, 2016: 68). $\mathrm{Bu}$ işlem Eşitlik (5) ile gerçekleştirilir. $X_{i j}{ }^{*} ; i$. alternatifinin $j$. kriteri için olan değerinin normalleştirilmiş değeridir. 


$$
X_{i j}^{*}=\frac{x_{i j}}{\sqrt{\sum_{i=1}^{m} x_{i j}^{2}}}
$$

3. Adım: Normalizasyon işleminden sonra hazırlanan tabloda kriterler, maksimum veya minimum olmalarına göre belirlenip toplanırlar ve toplanan maksimum kriterlerin değerinden toplanan minimum kriterlerin değeri çıkartılır.

Yani $j=1,2, \ldots, g$ maksimize edilecek kriterler, $j=g+1, g+2$, $\ldots, n$ minimize edilecek kriterler olmak üzere aşağıdaki Eşitlik (6) gibi yazılabilir.

$$
y_{i}^{*}=\sum_{j=1}^{g} x_{i j}^{*}-\sum_{j=g+1}^{n} x_{i j}^{*}
$$

$y_{i}{ }^{*} ; i$ alternatifinin tüm kriterlere göre normalleştirilmiş değerlendirilmesidir. $y_{i}^{*}$ lerin siralanmasıyla oran metoduna göre işlem tamamlanmış olur (Özcan ve Ömürbek 2016: 68; Yıldırım ve Önder, 2015: 247; Aksoy vd., 2015: 10; Yükçü ve Kaplanoğlu, 2015: 591).

4. Adım: Referans noktası yaklaşımında, oran metoduna ek olarak, her kriter için; amaç maksimizasyon ise maksimum noktalar, amaç minimizasyon ise minimum noktalar olan, referans noktaları ( $r_{i}$ 'ler) belirlenir. Belirlenen bu noktaların, her $x_{i j}{ }^{*}$ ile uzaklıkları bulunur. Yani;

$$
\left|r_{i}-x_{i j}^{*}\right|
$$

işlemi yapılır ve matris olarak yazılır. Burada;

$$
i=1,2, \ldots, m \text { alternatiflerin sayısını, }
$$

$j=1,2, \ldots \ldots, n$ kriterlerin sayısını, değerini,

$x_{i j}{ }^{*}=i$. alternatifin $j$. kriterindeki normalleştirilmiş

$r_{i}=i$. alternatifin referans noktasını göstermektedir

(Özcan ve Ömürbek, 2016: 68; Yıldırım ve Önder, 2015: 248).

Oluşturulan yeni matrise,' Tchebycheff min - maks metrik' işlemi

$$
\min _{j}\left\{\operatorname{maksi}\left(\left|r_{i}-x_{i j} *\right|\right)\right\}
$$

uygulanır. Her bir alternatifteki maksimum değerler seçilip sıralanır. Referans noktası yaklaşımına göre sıralama yapılmış olunur (Aksoy vd., 2015: 10; Yükçü ve Kaplanoğlu, 2015: 592; Yıldırım ve Önder 2015: 248).

$\mathrm{Bu}$ yaklaşımda gerek görüldüğü takdirde her bir kriterin ağırlığını gösteren "önem katsayısı" oranı uygulanabilir. Bu işlem Eşitlik (9) da gösterilmiştir (Brauers ve Zavadskas, 2012: 10; Özbek, 2017: 187). Böylece kriter ağırlıklı referans noktası yaklaşımına göre sıralama yapılmış olur.

$$
d_{i j}=\left|w_{j} r_{i}-w_{j} x_{i j}^{*}\right|
$$

5. Adım: Tam Çarpım Formu Yaklaşımında amaçların değerleri, çarpımlar şeklinde ifade edildiğinde; $x_{i j}$ değerleri eşitlik (10) yardımıyla düzenlenir (Çalış vd., 2016: 38; Özcan ve Ömürbek, 2016: 69; Aksoy vd., 2015: 11). Sürecin başında belirlenmiş olan maksimizasyon verileri çarpılarak minimizasyon verilerinin çarpımına bölünmektedir. Böylece $U_{j}$ değerleri elde edilmiş olur ve bu değerler büyükten küçüğe doğru sıralandığında tam çarpım formuna göre işlem tamamlanmış olur (Özbek, 2017: 187).

$$
U_{j}=\frac{A_{j}}{B_{j}} \quad A_{j}=\prod_{j=1}^{g} x_{i j}, B_{j}=\prod_{j=g+1}^{n} x_{i j}
$$

Burada;

$U_{j}=$ Alternatiflerin uygulanabilirliğ $\mathrm{i}$

$A_{j}=$ Maksimize edilecek kriterlerin normalize değerlerinin çarpım değeri

$B_{j}=$ Minimize edilecek kriterlerin normalize değerlerinin çarpım değeri

$i=1,2, \ldots, \mathrm{m}$ alternatiflerinin sayısı

$j=1,2, \ldots, n$ kriterlerinin sayıs

6. Adım: Bazı durumlarda bir amaç (kriter) bir diğerinden daha çok veya daha az öneme sahip olabilir. Böyle bir durumla karşılaşıldığında, bazı kriterlere fazla bazılarına daha az önem atfetmek için bir alternatifin normalize edilmiş değeri önem katsayısıyla çarpılır (Önay ve Çetin, 2012: 95; Brauers, vd., 2010: 618; Brauers ve Zavadskas, 2012: 10; Özbek, 2017: 186; Y1ldırım ve Önder, 2015: 248).

Seçeneklerin performans değerleri Eşitlik (11)'e göre hesaplanır:

$$
y_{i}^{*}=\sum_{j=1}^{g} s_{j} x_{i j}^{*}-\sum_{j=g+1}^{n} s_{j} x_{i j}^{*}
$$

$\mathrm{Bu}$ formülde,

$j=1,2, \ldots, g$ maksimize edilecek kriterler,

$j=g+1, g+2, \ldots, n$ minimize edilecek kriterler,

$y_{i}{ }^{*} ; i$. alternatifinin önem katsayısıyla tüm amaçlara göre normalleştirilmiş değerlendirilmesi,

$S_{j}, j$. kriterinin önem katsayısıdır. (Yıldırım ve Önay, 2013: 70; Yildırım ve Önder, 2015: 248),

$y_{i}{ }^{*} \quad$ değerlerinin büyükten küçüğe doğru sıralanmasıyla önem katsayısı yaklaşımına göre işlem tamamlanmış olur.

7. Adım: MOORA Oran Metodu, Referans Noktası Yaklaşımı ve Tam Çarpım Formu yöntemleri uygulandıktan sonra, yapılan sıralamalar toplu bir şekilde değerlendirilir. Baskınlık karşılaştırması ile MULTIMOORA sıralamasına ulaşılır (Özcan ve Ömürbek, 2016: 69). MULTIMOORA tek başına kullanılan bir teknik değildir. Diğer MOORA teknikleri sonucu yapılan sıralamaların en son baskınlıklarına göre değerlendirerek tek bir sıralamada birleştirilmesi ile MULTIMOORA sıralaması oluşturulur (Aksoy vd., 2015: 9; Özbek, 2017: 188).

\section{Uygulama}

Bu bölümde öncelikle çalışmada kullanılan ana kriterler ve alt kriterlerin açıklamalarına yer verilmiştir. Daha sonra kurumsal müşterilerin tercihleri doğrultusunda sıralanan kriterler SWARA yöntemi ile ağırlıklandırılmış ve sonrasında yine kurumsal müşterilerin banka tercihleri MOORA yöntemiyle değerlendirilmiştir. Haksız rekabete sebebiyet vermemek amacıyla banka isimleri gizli tutulmuş, çalışmada bankalar alternatif 1, 2, 3 şeklinde adlandırılmıştır.

\section{1. Çalışmada Kullanılan Kriterler}

Literatürde tüketicilerin banka tercihini etkileyen kriterlerden faydalanılarak çalışmada kullanılacak olan kriterler belirlenmiştir. Çalışmada kurumsal banka müşterilerinin banka tercihine etki eden kriterler; bankanın fiziki özellikleri ve teknik yapısı, banka personelinin özellikleri, işlem kolaylığı ve maliyeti, ürün ve hizmet çeşitliliğii, bankanın güvenilirliği, erişim kolaylığı, bankanın imajı/itibarı ve kuruma bağlılık olmak üzere sekiz ana kriter olarak belirlenmiştir. Her bir ana 
kriter de alt kriterlere ayrılmıș ve toplamda 29 alt kriter belirlenmiştir. Belirlenen ana ve alt kriterlerin adlandırmaları aşağıdaki gibidir:

Tablo 1. Ana ve Alt Kriterler

\begin{tabular}{|c|c|}
\hline Ana Kriterler & Alt Kriterler \\
\hline \multirow{3}{*}{$\begin{array}{c}\text { C1 - Bankanın } \\
\text { Fiziki } \\
\text { Özellikleri ve } \\
\text { Teknik Yapısı }\end{array}$} & C11 - Bankanın finansal gücü \\
\hline & C12 - Bankanın iç-dış görünümü \\
\hline & $\begin{array}{l}\text { C13 - Bankanın teknolojik altyapısı ve teknolojiyi } \\
\text { yakından takip etme durumu }\end{array}$ \\
\hline \multirow{4}{*}{$\begin{array}{c}\text { C2 - Banka } \\
\text { Personelinin } \\
\text { Özellikleri }\end{array}$} & C21 - Personeli bilgili ve konusuna vakıf olması \\
\hline & C22 - Personelin işlemleri hızlı ve doğru sonuçlandırmas \\
\hline & C23 - Personelin yol gösterici ve yardımsever olması \\
\hline & C24 - Personelin iyi müşteri ilişkileri ve bağlantıları \\
\hline \multirow{4}{*}{$\begin{array}{l}\text { C3 - İşlem } \\
\text { Kolaylığı ve } \\
\text { Maliyeti }\end{array}$} & C31 - Kredi kullanma kolaylı̆̆ı \\
\hline & C32 - Bürokratik işlemlerin az olması \\
\hline & C33 - Yapılan işlemlerden düşük masraf alınması \\
\hline & C34 - Verilen faizin yüksek olmas1 \\
\hline \multirow{4}{*}{$\begin{array}{c}\text { C4 - Ürün ve } \\
\text { Hizmet } \\
\text { Çeşitliliği }\end{array}$} & C41 - Kredi olanaklarının çeşitliliği \\
\hline & \begin{tabular}{|l|} 
C42 - Çek defteri vermesi \\
\end{tabular} \\
\hline & C43 - Finansal danışmanlık hizmeti sağlanması \\
\hline & $\begin{array}{l}\text { C44 - Değişen pazar ihtiyaçlarına yönelik yeni ürünlerin } \\
\text { sunulamaması }\end{array}$ \\
\hline \multirow{5}{*}{$\begin{array}{l}\text { C5 - Bankanın } \\
\text { Güvenilirliği }\end{array}$} & C51 - Kişisel bilgilerin saklanması \\
\hline & C52 - Bankanın uzun zamanadır faaliyette bulunmas1 \\
\hline & C53 - Bankanın tavsiye edilmesi \\
\hline & C54 - Devlet bankası olması \\
\hline & C55 - Sürekli hatalı işlemlerle karşılaşılması \\
\hline \multirow{2}{*}{$\begin{array}{l}\text { C6 - Erişim } \\
\text { Kolaylığ } 1\end{array}$} & C61 - Bankanın uygun yerleşim yeri \\
\hline & C62 - Bankanın üst düzey yöneticilerine ulaşma zorluğu \\
\hline \multirow{3}{*}{$\begin{array}{l}\text { C7 - Bankanın } \\
\text { İmajı/İtibarı }\end{array}$} & C71 - Bankanın tanınmışlı̆̆ı \\
\hline & C72 - Çevre dostu olması \\
\hline & C73 - Bankanın toplumsal konulara hassasiyeti \\
\hline \multirow{4}{*}{$\begin{array}{l}\text { C8 - Kuruma } \\
\text { Bağll11k }\end{array}$} & C81 - Bankanın sunduğu hizmet kalitesinin sürekliliği \\
\hline & C82 - Bankanın müşterilerine kişisel ilgi göstermesi \\
\hline & C83 - Katılım (faizsiz) bankası olması \\
\hline & C84 - Personelin eş dost, tanıdık, akraba olması \\
\hline
\end{tabular}

Aydın Ticaret Odası'ndan (AYTO), Aydın ilinde faaliyet gösteren sektörler (meslek grupları) ve firma sayıları bilgisi elde edilmiştir. Elde edilen bilgi doğrultusunda hangi meslek grubundan kaç kurumsal firma ile görüşülüp anket yapılacağı belirlenmiştir. AYTO’ ya kayıtlı toplam 17 meslek grubuna ait olan toplam 6128 üye sayısı olduğu sonucuna ulaşılmıştır. Çalışmada 10 firma ile görüşülmesinin, elde edilecek veri yeterliliği açısından uygun olacağına karar verilmiş ve her meslek grubundan kaç firma ile görüşüleceği belirlenmiştir. Böylece kriterlerin önem düzeyleri ve karşılaştırmalı öneminin belirleneceği birinci anket için görüşülecek sektörler belirlenmiştir. $\mathrm{Bu}$ sektörlerden "tarım ürünleri" meslek grubundan 1, "eğitim sağlık" meslek grubundan 1, "inşaat" meslek grubundan 2, "inşaat destekleyici faaliyetler" meslek grubundan 1, "toptan ve perakende" meslek grubundan 1, "motorlu araçlar, yakıt ve yedek parçaları" meslek grubundan 1, "madencilik, kimyasallar, metal sanayi, makine" meslek grubundan 1, "teknik danışmanlık ve müşavirlik" meslek grubundan 1 ve "hububat, firıncılık ürünleri ve muhtelif tatlılar" meslek grubundan 1 olmak üzere toplamda 10 firma ile kriterler görüşülmüştür.

Anketin ikinci kısmında ise belirlenen meslek gruplarından toplam 10 firma ile alternatifler ve kriterler görüşülmüştür. Buradaki alternatifler "Türkiye Bankalar Birliği" sitesinden yararlanılarak elde edilen Aydın il merkezinde (Efeler) faaliyet gösteren 15 banka ve "Türkiye Katılım Bankaları Birliği" sitesinden elde edilen 5 bankadır. Kriterler ise anketin ilk kısmında firma yöneticileri ile görüşülen, firmaların banka tercihinde etkili olan faktörlerdir. İkinci anket için kurumsal firma yöneticileri 17 alternatif ve 29 kriteri değerlendirmiştir.
$\mathrm{Bu}$ çalışmada, Aydın ilinde faaliyette bulunan kurumsal firmaların banka tercihinde etkili olan kriterleri ve önem derecelerini belirlemede SWARA yönteminden yararlanılmış daha sonra MOORA yöntemi ile alternatif bankaları değerlendirme işlemi yapılmıştır.

\subsection{Kriterlerin SWARA Yöntemi ile Ağırlıklandırılması Aşaması}

Değerlendirme kriterlerinin önem düzeylerinin belirlenmesi için 10 karar verici (KV) ile birebir görüşülerek anket uygulanmıştır. Öncelikle, karar vericilerden kriterleri kendilerine göre en önemliden, en az önemliye sıralamaları istenmiştir. SWARA yöntemi 1. adım uygulanarak Ek 1 ve Ek 2 'de karar vericilere ait sıralamalara ulaşılmıştır. SWARA yöntemi 2. adım ile karar vericilere Ek 1 ve Ek 2'de kendilerine ait kriter sıralamalarını dikkate alarak kriterler arası karşılaştırma işlemini 0,05 ile 0,95 arasında 5'in katları biçiminde yapmaları istenmiştir. Böylece Ek 3 ve Ek 4'te karar vericilerin ana kriterler ile alt kriterlerin karşılaştırma matrislerine ulaşılmıştır.

Karar vericilerden elde edilen verilere Eşitlik (1), Eşitlik (2) ve Eşitlik (3) uygulanmış, her bir karar vericiye ait ana kriter ağırlıkları (Ek 7) ve alt kriter ağırlıkları (Ek 8) bulunmuştur (Ek 5 ve Ek 6'da karar verici 1'e ait ana ve alt kriterlere ait hesaplamalara yer verilmiştir). Sonrasında, bu ağırlıkların bütünleştirme işlemi yapılmış (Ek 9), Tablo 2'de özet olarak verilen nihai alt kriter ağırlıklarına ulaşılmıştır.

Tablo 2. SWARA Yöntemi Sonucu Kriter Ağırlıkları

\begin{tabular}{|c|c|c|c|c|c|c|c|}
\hline 承 & 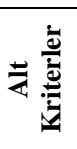 & 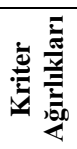 & 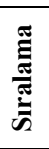 & 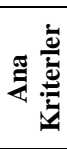 & 艺离 & 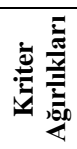 & \\
\hline \multirow{3}{*}{$\mathrm{C} 1$} & C11 & 0,028 & 14 & \multirow{5}{*}{ C5 } & C51 & 0,066 & 5 \\
\hline & $\mathrm{C} 12$ & 0,012 & 21 & & C52 & 0,058 & 8 \\
\hline & $\mathrm{C} 13$ & 0,023 & 16 & & C53 & 0,032 & 13 \\
\hline \multirow{4}{*}{ C2 } & $\mathrm{C} 21$ & 0,010 & 25 & & C54 & 0,071 & 2 \\
\hline & $\mathrm{C} 22$ & 0,012 & 23 & & C55 & 0,020 & 18 \\
\hline & $\mathrm{C} 23$ & 0,009 & 26 & \multirow{2}{*}{ C6 } & C61 & 0,114 & 1 \\
\hline & C24 & 0,006 & 28 & & C62 & 0,066 & 6 \\
\hline \multirow{4}{*}{ C3 } & C31 & 0,068 & 4 & \multirow{3}{*}{ C7 } & C71 & 0,059 & 7 \\
\hline & C32 & 0,042 & 10 & & $\mathrm{C} 72$ & 0,035 & 12 \\
\hline & C33 & 0,071 & 3 & & $\mathrm{C} 73$ & 0,046 & 9 \\
\hline & C34 & 0,025 & 15 & \multirow{4}{*}{ C8 } & C81 & 0,037 & 11 \\
\hline \multirow{4}{*}{ C4 } & C41 & 0,017 & 19 & & $\mathrm{C} 82$ & 0,021 & 17 \\
\hline & $\mathrm{C} 42$ & 0,009 & 27 & & $\mathrm{C} 83$ & 0,012 & 22 \\
\hline & $\mathrm{C} 43$ & 0,014 & 20 & & $\mathrm{C} 84$ & 0,010 & 24 \\
\hline & $\mathrm{C} 44$ & 0,006 & 29 & & & & \\
\hline
\end{tabular}

Karar vericilerin yaptı̆̆ değerlendirmeler sonucunda en önemli kriterin, 0,114 değeriyle "C61 - Bankanın uygun yerleşim yeri” kriteri olduğu sonucuna ulaşılmıştır. Daha sonra "C54 - Devlet bankası olması", "C33 - Yapılan işlemlerden düşük masraf alınması” şeklinde sıralama devam etmektedir. Tablo 2'nin son sütununda kriterlere ait siralamaya yer verilmiştir.

$\mathrm{Bu}$ aşamadan sonra yapılacak olan işlem; elde edilen nihai kriter ağırlıkları dikkate alınarak MOORA yöntemi ile alternatif bankaların değerlendirilmesi işleminin yapılmasıdır.

\subsection{Alternatif Bankaların MOORA Yöntemi ile Değerlendirilmesi Aşaması}

Tablo 2'deki alt kriterleri dikkate alarak karar vericilerden alternatif bankaları 5 ile 100 arası puan verilerek 
değerlendirme yapmaları istenmiștir. Her bir karar vericiden elde edilen değerlendirme değerlerinin geometrik ortalamasının alınması ile Ek (10)'daki bütünleştirilmiş karar matrisine ulaşılmıştır. Bütünleştirilmiş karar matrisinin normalizasyon işlemi sonrası normalize karar matrisine Ek (11)'de yer verilmiştir. Normalize karar matrisinden faydalanarak Eşitlik (6) ile MOORA - Oran Metoduna göre yapılan hesaplama ve sıralamaya Ek 12'de; Eşitlik (7) ve Eşitlik (8) ile MOORA - Referans Noktası Yaklaşımına göre yapılan hesaplama ve sıralamaya Ek 13'te; Eşitlik (10) ile MOORA - Tam Çarpım Formu Yaklaşımına göre yapılan hesaplama ve siralamaya Ek 14'te; Eşitlik (11) ile MOORA Önem Katsayısı Yaklaşımına göre hesaplama ve sıralamaya Ek 15'te; Eşitlik 9 ile MOORA - Kriter Ağırlıklı Referans Noktası Yaklaşımına göre yapılan hesaplama ve sıralamaya Ek 16'da yer verilmiştir.

Her bir sıralamaya ilişkin baskınlık karşılaştırması yapılarak MULTIMOORA sıralaması ortaya konulmuştur. Tablo 3'te hesaplamalar neticesinde oluşturulan tüm sıralamalara yer verilmiştir.

Tablo 3. MOORA Yöntemi Sonuç Tablosu

\begin{tabular}{|c|c|c|c|c|c|c|}
\hline & & & & & \\
\hline & & & & & \\
\hline $\mathrm{A} 1$ & 8 & 11 & 8 & 8 & 6 & 8 \\
\hline $\mathrm{A} 2$ & 16 & 15 & 16 & 16 & 15 & 16 \\
\hline $\mathrm{A} 3$ & 15 & 14 & 15 & 15 & 16 & 15 \\
\hline $\mathrm{A} 4$ & 13 & 13 & 13 & 13 & 13 & 13 \\
\hline $\mathrm{A} 5$ & 7 & 7 & 7 & 7 & 6 & 7 \\
\hline $\mathrm{A} 6$ & 14 & 17 & 14 & 14 & 14 & 14 \\
\hline $\mathrm{A} 7$ & 10 & 9 & 10 & 11 & 12 & 10 \\
\hline $\mathrm{A} 8$ & 17 & 16 & 17 & 17 & 17 & 17 \\
\hline $\mathrm{A} 9$ & 9 & 10 & 9 & 9 & 10 & 9 \\
\hline $\mathrm{A} 10$ & 12 & 8 & 12 & 12 & 11 & 12 \\
\hline $\mathrm{A} 11$ & 11 & 12 & 11 & 10 & 9 & 11 \\
\hline $\mathrm{A} 12$ & 1 & 1 & 1 & 2 & 3 & 1 \\
\hline $\mathrm{A} 13$ & 4 & 5 & 4 & 4 & 4 & 4 \\
\hline $\mathrm{A} 14$ & 3 & 2 & 3 & 3 & 1 & 3 \\
\hline $\mathrm{A} 15$ & 2 & 3 & 2 & 1 & 2 & 2 \\
\hline $\mathrm{A} 16$ & 6 & 4 & 6 & 5 & 8 & 6 \\
\hline $\mathrm{A} 17$ & 5 & 6 & 5 & 6 & 5 & 5 \\
\hline
\end{tabular}

Tablo 3'e bakıldığında en iyi konuma sahip olan A12 bankası, en kötü sonuca sahip olan ise A8 bankası olmuştur. MOORA oran metoduna göre alternatif bankaların sıralaması en iyiden en kötüye şu şekildedir: A12, A15, A14, A13, A17, A16, A5, A1, A9, A7, A11, A10, A4, A6, A3, A2, A8. MOORA referans noktası yaklaşımına göre alternatif bankaların sıralaması en iyiden kötüye şu şekildedir: A12, A14, A15, A16, A13, A17, A5, A10, A7, A9, A1, A11, A4, A3, A2, A8, A6. MOORA tam çarpım formu yaklaşımına göre alternatif bankaların sıralaması en iyiden kötüye şu şekildedir: A12, A15, A14, A13, A17, A16, A5, A1, A9, A7, A11, A10, A4, A6, A3, A2, A8. MOORA önem katsayısı yaklaşımına göre alternatif bankaların sıralaması en iyiden kötüye şu şekildedir: A15, A12, A14, A13, A16, A17, A5, A1, A9, A11, A7, A10, A4, A6, A3, A2, A8. Kriter ağırlıklı referans noktası yaklaşımına göre alternatif bankaların sıralaması en iyiden kötüye şu şekildedir: A14, A15, A12, A13, A17, A5, A1, A16, A11, A9, A10, A7, A4, A6, A2, A3, A8. Tüm bu yaklaşımlardan sonra baskınlıklarına göre MULTIMOORA siralamaları en iyiden kötüye s1rasıyla A12, A15, A14, A13, A17, A16, A5, A1, A9, A7, A11, A10, A4, A6, A3, A2, A8 biçiminde devam etmiştir.

\section{Sonuç ve Öneriler}

Bankacılık sektörü ülke ekonomilerinde önemli bir yere sahiptir. Dolayısıyla bankacılık sektöründeki gelişme ekonomik gelişmeye de katkı sağlayacaktır. Bankacılık sektöründeki yoğun rekabet ise bankaların müşteri memnuniyeti sağlaması konusunda oldukça önemli bir konu haline gelmiştir. Bankaların pazarda büyük bir paya sahip olabilmeleri müşteri odaklı olmalarını gerektirmektedir. Pazardaki rekabet ortamı, müşterilerin banka tercihlerini istedikleri gibi yapmalarına olanak vermektedir. Bu sebepten müşteri memnuniyetinin sağlanması için bankaların müşteri tercihine etki eden kriterleri iyi tespit etmesi ve kendilerini bu kriterler üzerinde geliştirmesi gerekmektedir.

Bankalar ile kredi ilişkisi içindeki işletmeler, bankalara parasını emanet eden tasarruf sahipleri, bankalara kredi veren mali kuruluşlar, bankanın ortakları ve Merkez Bankası, bankaların performanslarıyla bilgi sahibi olmak isterler. Dolayısıyla ÇKKV yöntemleri, analiz yöntemi olarak bankaların değerlendirilmesinde uygulanabilmektedir.

Çalışmanın önemi, mevcut yazında banka tercihinde çoğunlukla performans değerlemede somut sayısal verilerden yararlanılmıştır. Bu çalışmada daha güncel ve müşteri odaklı sonuçlar getireceğine inanılan öznel verilerden yararlanılmıştır.

$\mathrm{Bu}$ çalışmada banka müşterisi konumundaki kurumsal firmaların tercihlerinde etkili olan kriterlerin SWARA yöntemi ile önem dereceleri bulunmuş, alternatif bankalar MOORA yöntemi ile değerlendirilmiştir. MOORA yöntemi diğer ÇKKV tekniklerine göre, hesaplama zamanı az, uygulaması daha basit, matematik işlemleri sayısı daha az ve güvenilirlik bakımından tatmin edici olması gibi üstünlükleri bulunması sebebiyle çalışmada kullanılmak üzere tercih edilmiştir.

İşletmelerin banka tercihinde etkili olan pek çok kriter mevcuttur. Bu bağlamda çalışmanın amacı Aydın ilinde faaliyette bulunan bankaların tercihini etkileyen kriterlerin önem derecesini tespit etmek ve bu kriterler çerçevesinde bankaları değerlendirmektir.

Çalışmada bankaların tercih edilmesinde etkili olan 8 ana kriter ve 29 alt kriter belirlenmiştir.

Çalışmaya bankaların değerlendirme kriterlerinin önem düzeylerinin belirlenmesiyle başlanmıştır. Kriterlerin önem düzeylerinin belirlenmesinde kurumsal firma yöneticilerinin öznel görüşleri alınmış, elde edilen veriler SWARA yöntemiyle analiz edilmiştir. Yapılan araştırma sonucunda, kriterler arasında en önemli olanı "bankanın uygun yerleşim yeri" olarak belirlenmiştir. Bu sonuca göre, bankaların tercih edilmesinde müşteri memnuniyeti sağlamada erişim kolaylığına önem vermelerini, şubelerinin iş yerlerine yakın yerlerde olmasına ve araç park yeri bulunmasına, ATM'lerin yaygın ve işlem yapabilir durumda olmasına dikkat etmesi gerektiğini ortaya koymaktadır.

Analize göre en önemli kriter; 0,114 değeriyle "bankanın uygun yerleşim yeri”" olurken, diğer kriterin önem düzeyleri ise sırasıyla "devlet bankası olması $(0,071)$ ", "yapılan işlemlerden düşük masraf alınması $(0,071)$ ", "kredi kullanma kolaylığı 
$(0,068)$ ", "kişisel bilgilerin saklanması $(0,066)$ ", "bankanın yöneticilerine ulaşma zorluğu $(0,066)$ ", "bankanın tanınmışlığı $(0,059)$ ", "bankanın uzun zamanadır faaliyette bulunması $(0,058)$ ", "bankanın toplumsal konulara hassasiyeti $(0,046)$ ", "bürokratik işlemlerin az olması $(0,042)$ ", "bankanın sunduğu hizmet kalitesinin sürekliliği $(0,037)$ ", "çevre dostu olmasi (0,035)", "bankanın tavsiye edilmesi $(0,032)$,, "bankanın finansal gücü $(0,028)$ ", "verilen faizin yüksek olması (0,025)", "bankanın teknolojik altyapısı $(0,023)$ ", "bankanın müşterilerine kişisel ilgi göstermesi $(0,021)$ ", "Sürekli hatalı işlemlerle karşılaşılması $(0,020)$ ", "Kredi olanaklarının çeşitliliği (0,017)", “finansal danışmanlık hizmeti sağlanması $(0,014)$ ", "bankanın iç-dış görünümü $(0,012)$ ", "katılım (faizsiz) bankası olması $(0,012)$ ", "işlemleri hızlı ve doğru sonuçlandırması $(0,012)$ ", "personelin eş dost, tanıdık, akraba olması $(0,010)$ ", “personelin bilgili ve konusuna vakıf olması $(0,010)$ ", "yol gösterici ve yardımsever olmasi $(0,009)$ ", "çek defteri vermesi $(0,009)$ ", "personelin iyi müşteri ilişkileri ve bağlantıları $(0,006)$ ", "yeni ürünlerin sunulamaması $(0,006)$ " olarak bulunmuştur.

Çalışmanın ikinci kısmında ise, alternatif olarak önerilen bankalar arasından, uygulamanın yapıldı ̆̆ firma yöneticileri için en çok tercih edilen bankaların ÇKKV yöntemlerinden MOORA yöntemi ile sıralanması işlemi yapılmıştır. Aydın ilinde faaliyet gösteren bankalar alternatifler olarak belirlenmiştir. Bankalar arası haksız rekabete sebebiyet vermemek amaciyla banka isimleri gizli tutulmuş ve bankalar Alternatif 1 (A1), Alternatif 2 (A2), ..., Alternatif 17 (A17) olarak isimlendirilmiştir. Bunun yapılması için on karar vericiden kriterleri dikkate alarak alternatif bankaları değerlendirmeleri istenmiştir. $\mathrm{Bu}$ on karar vericinin değerlendirmeleri geometrik ortalamaları ile bütünleştirilip grup kararına dönüştürülerek bütünleşik karar matrisi oluşturulmuştur. Bütünleşik karar matrisinin normalize edilmesi sonrası MOORA yöntemi adımları uygulanmıştır. MOORA yöntemi ile elde edilen sonuca göre A12 bankasının karar vericilerin öznel değerlendirmeleri ile ilk sırada olduğu sonucuna ulaşılmıştır. MOORA oran metoduna göre sıralamadaki en iyi banka A12, en son siradaki banka A8 şeklinde bulunmuştur. MOORA referans noktası yaklaşımına göre en iyi banka A12, son sıradaki banka A6 olarak bulunmuştur. MOORA tam çarpım formu yaklaşımına göre en iyi banka A12, son sıradaki banka A8 şeklindedir. MOORA önem katsayısı yaklaşımına göre en iyi banka A15, son sıradaki banka A8, Kriter ağırlıklı referans noktası yaklaşımına göre en iyi banka A14, son sıradaki banka A8 olmuştur. Tüm bu yaklaşımlardan sonra baskınlıklarına göre MULTIMOORA sıralamaları en iyiden kötüye sırasıyla A12, A15, A14, A13, A17, A16, A5, A1, A9, A7, A11, A10, A4, A6, A3, A2, A8 biçiminde devam etmiştir.

Yapılan bu çalışma neticesinde kurumsal müşterilerin banka tercihinde etkili olan kriterleri düşünerek bankaların tercih edilebilirliklerini arttırmak ve bankalara müşteri memnuniyeti sağlama konularıyla ilgili olarak;

- Bankalar erişim kolaylığına önem vermeli, müşterilerin rahatça ulaşabileceği yerlerde konumlanıp, yaygın ATM ile hizmet vermelidir,

- Bankalar kişisel bilgilerin saklanması konusunda müşterilerde güven sağlamalı, güvenilirlik kriterine önem vermeli,

- Çalışma sonucunda önem düzeyinde üçüncü sırada yer alan "yapılan işlemlerden düşük masraf alınması" kriteri göz önünde bulundurulmalı ve hesap ișletim ücretleri ve komisyon giderleri minimum seviyede tutulmalı,

- Müşterinin talebi doğrultusunda bankanın yönetim kadrosu ile görüşebilmesi mümkün olmalı,

- Bankalar tutundurma faaliyetlerine önem verip tanınmışlığını arttırmalı,

- Bankalar sosyal sorumluluk projelerine önem vererek toplumsal konulara hassas olduklarını göstermeli müşterilerin sempatisini kazanmalı,

- Bankalar müşterilerinin kredi ihtiyacına kısa sürede cevap verebilmeli, vade konusunda müşteri tercihlerini önemsemeli,

- Bankaların müşterilerine sundukları faiz oranlarında müşteri tercihlerini önemsemeli,

- Bankalar finansal güçlerine önem vermeli ve likiditesini arttırmal1,

- Bankalar iç-dış görünümüne önem vermeli, tasarım, donanım, konfor ve iletişim araçlarıyla modern bir yapıda olmal1,

- Bankalar teknolojik alt yapılarını geliştirmeli, internet bankacılığına önem vermeli,

- Bankalar sunduğu hizmet kalitesinin sürekliliğini sağlamalı; müşterisini yeni hizmetlerden haberdar edip, düzenli hesap özeti göndermeli,

- Bankalar belirli aralıklarda promosyonlar yapıp müşteri beklentilerini karşılamalı,

- Bankalar müşterilerine kişisel ilgi göstermeli, düzenli müşterilerin farkında olmalı,

- Bankalar hedefledikleri müşteri kitlesinin özelliklerine göre çalışmalar yapmalı,

- Bankada çalışan personel bilgili, hızlı ve doğru işlem yapan, yardımsever ve müşteriyle iyi iletişim kurabilen vb. nitelikte olmal1,

- Bankalar müşterilerinin memnuiyetlerini düzenli aralıklarla ölçmelidirler,

şeklinde önerilebilir.

$\mathrm{Bu}$ çalışma, mevcut literatür bilgisini genişletmeye ve banka seçiminde kurumsal müşterilerin önem verdikleri kriterleri belirlemeye yardımcı olmaktadır. $\mathrm{Bu}$ çalışmada sadece bankacılık sektörü ele alınmıştır. Bu çalışmada ele alınan konu diğer sektörlere de uygulanabilir. Çalışmada kurumsal firma yöneticilerinin (kurumsal müşterilerin) tercihlerindeki kriterler dikkate alınmıştır. Benzer şekilde, ileride yapılacak çalışmalarda bireysel müşterilerin tercihleri dikkate alınarak banka seçimleri incelenebilir. Yine kriterlerin ağırlıklandırılması ve alternatiflerin seçimi aşamasında farklı ÇKKV yöntemleri kullanılarak elde edilen sonuçlar bu çalışmanın sonuçları ile karşılaştırılabilir. Ayrıca, bu çalışmada ele alınan bankaların seçimi, literatür incelemesi sonucu oluşturulan kriterlerce, karar vericilerin öznel değerlendirmeleri dikkate alınarak incelenmiştir. Gelecekteki araştırmalar, bu araştırmada incelenen kriterlerin sayısını artırabilir ya da azaltabilir ve karar verici sayısı da değiştirilerek sonuçlar karşılaştırılabilir. 


\section{Kaynakça}

Akçakanat, Ö., Eren, H., Aksoy, E., \& Ömürbek, V. (2017) Bankacılık sektöründe ENTROPİ ve WASPAS yöntemleri ile performans değerlendirmesi. Süleyman Demirel Üniversitesi İktisadi ve İdari Bilimler Fakültesi Dergisi, 22(2), 285-300.

Aksoy, E., Ömürbek, N., \& Karaatl1, M. (2015). AHP temelli MULTIMOORA ve COPRAS yöntemi ile Türkiye Kömür İşletmeleri'nin performans değerlendirmesi. Hacettepe Üniversitesi İktisadi ve İdari Bilimler Fakültesi Dergisi, 33(4), 1-28.

Albayrak, Y. E., \& Erkut, H. (2005). Banka performans değerlendirmede analitik hiyerarşi süreç yaklaşımı, ITÜ Mühendislik Dergisi, 4(6), 47-58.

Almahmeed, M. A., \& Thabet, A. E. (1997). Services considered important to business customers and determinants of bank selection in Kuwait: A segmentation analysis. International Journal of Bank Marketing, 15(4), 126-133.

Almossawi, M. (2001). Bank selection criteria employed by college students in Bahrain: An empirical analysis. The International Journal of Bank Marketing, 19(3), 115-125.

Amile, M., Sedaghat, M., \& Poorhossein, M. (2013). Performance evaluation of banks using fuzzy AHP and TOPSIS, case study: State-Owned banks, partially private and private banks in Iran. Caspian Journal of Applied Sciences Research, 2(3), 128-138.

Avcıkurt, C., \& Köroğlu, Ö. (2006). Termal otel işletmelerinde müşteri sadakatini artıran nitelikleri belirlemeye yönelik bir alan araştırması. Seyahat ve Otel Işsletmeciliği Dergisi, $1(3), 6$.

Awan, H. M., \& Bukhari, K. S. (2011). Customer's criteria for selecting an Islamic bank: Evidence from Pakistan. Journal of Islamic Marketing, 2(1), 14-27.

Bağc1, H., \& Rençber, Ö. F. (2014). Kamu bankaları ve halka açık özel bankaların PROMETHEE yöntemi ile karlılıklarının analizi. Aksaray Üniversitesi İktisadi ve İdari Bilimler Fakültesi Dergisi, 6(1), 39- 47.

Bei, L. T., \& Shang C. F. (2006). Building marketing strategies for state-owned enterprises against private ones based on the perspectives of customer satisfaction and service quality. Journal of Retailing and Consumer Services, 13(1), 1-13.

Bergendahl, G., \& Lindblom, T. (2008). Evaluating the Performance of Swedish savings banks according to service efficiency. European Journal of Operational Research, 185, 1663-1673.

Blien, U., \& Tassinopoulos, A. (2001). Forecasting regional employment with the entropy method, Regional Studies, 35(2), 113-124.

Boyd, W. L., Leonard, M., \& White, C. (1994). Customer preferences for financial services: An analysis. The International Journal of Bank Marketing, 12(1), 9-15.

Brauers, W. K. M., Ginevicius, R., \& Podvezko, V. (2010). Regional development in Lithuania considering multiple objectives by the MOORA method. Technological and Economic Development of Economy, 16(4), 613-640.

Brauers, W. K. M., \& Ginevicius, R. (2009). Robustness in regional development studies: The case of Lithuania. Journal of Business Economics and Management, 10(2), 121-140.

Brauers, W. K. M., \& Zavadskas, E. K. (2006). The MOORA method and its application to privatization in a transition economy. Control and Cybernetics, 35(2), 445-469.

Brauers, W. K. M., \& Zavadskas, E. K. (2012). Robustness of MULTIMOORA: A method for multi-objective optimization. Informatica, 23(1), 1-25.

Cebeci, İ., \& Çabuk, Z. (2016). Tüketicilerin banka tercihini etkileyen faktörlerin belirlenmesi: Giresun'da bir araştırma. Finansal Araştırmalar ve Çalışmalar Dergisi, 8(14), 57-66.

Chigamba, C. \& Fatoki, O. (2011). Factors influencing the choice of commercial banks by university students in South Africa. International Journal of Business and Management, 6(6), 66-76.

Cho, K. T. (2003). Multicriteria decision methods: An attempt to evaluate and unify. Mathematical and Computer Modelling, Pergamon, 37(9-10), 1099-1119.

Coşkun, A. (2006). Bankaların stratejik performans yönetiminde performans karnesi kullanımı. Bankacılar Dergisi, 56, 28-39.

Çağıl, G. (2011). 2008 küresel kriz sürecinde Türk bankacılık sektörünün finansal performansının ELECTRE yöntemi ile analizi. Maliye Finans Yazlları, 25(93), 59-86.

Çakır, E. (2016). SWARA - Copeland yöntemi ile kriter ağırlıklarının belirlenmesi: Bir üretim işletmesinde uygulama. Aydın Adnan Menderes Üniversitesi Sosyal Bilimler Enstitüsü Dergisi, 4(1) 42-56.

Çakır, E., \& Sezen Akar, G. (2017). Bütünleşik SWARA TOPSIS yöntemi ile makine seçimi: bir üretim işletmesinde uygulama. International Journal of Academic Value Studies (Javstudies), 3(13), 206-216.

Çalış, A., Özçelik, G., \& Gencer, C. (2016). Türkiye'deki imalat sanayi sektörlerinin PROMETHEE MULTIMOORA ve SMAA-2 yöntemleriyle siralanması. Endüstri Mühendisliği Dergisi, 27(2), 28-44.

Çalışkan, E., \& Eren, T. (2016). Bankaların performanslarının çok kriterli karar verme yöntemiyle değerlendirilmesi. Ordu Üniversitesi Bilim Teknoloji Dergisi, 6(2), 85-107.

Çınar, R., \& Erciş A. (1993). Genç pazarın banka hizmetlerini tercihleri üzerine bir saha araştırması. Pazarlama Dünyası, 7(37), 6-22.

Çiçek, R., \& Doğan, İ. C. (2009). Müşteri memnuniyetinin artırılmasında hizmet kalitesinin ölçülmesine yönelik bir araştırma: Niğde ili örneği. Afyon Kocatepe Üniversitesi, I.I.B.F. Dergisi, 11(1), 199-217.

Demireli, E. (2010). TOPSIS çok kriterli karar verme sistemi: Türkiye'deki kamu bankaları üzerine bir uygulama. Girişimcilik ve Kalkınma Dergisi, 5(1), 101-112. 
Devlin, J., \& Gerrard, P. (2005). A Study of Customer Choice Criteria for Multiple Bank Users. Journal of Retailing and Consumer Services, 12(4), 297-306.

Dinçer, H., \& Görener, A. (2011). Analitik hiyerarşi süreci ve VIKOR tekniği ile dinamik performans analizi: Bankacılık sektöründe bir uygulama. İstanbul Ticaret Üniversitesi Sosyal Bilimler Dergisi, 10(19), 109-127.

Doumpos, M., \& Zopounidis, C. (2010). A multicriteria decision support system for bank rating. Decision Support Systems, 50(1), 55-63.

Ecer, F. (2013). Türkiye'deki özel bankaların finansal performanslarının karşılaştırılması: 2008-2011 dönemi. Abant İzet Baysal Üniversitesi Sosyal Bilimler Enstitüsü Dergisi, 13(2), 171- 189.

Ertuğrul, İ., \& Karakaşoğlu, N. (2009). Banka şube performanslarının VIKOR yöntemi ile değerlendirilmesi. Endüstri Mühendisliği Dergisi, 20(1), 19-28.

Genç, T., \& Masca, M. (2013). TOPSIS ve PROMETHEE yöntemleri ile elde edilen üstünlük sıralamalarının bir uygulama üzerinden karşılaştırılması. Afyon Kocatepe Üniversitesi IIIBF Dergisi, 15(2), 539-566.

Güneysu, Y., ER, B., \& AR, İ. M. (2015). Türkiye'deki ticari bankaların performanslarının AHS ve GİA yöntemleri ile incelenmesi. Karadeniz Teknik Üniversitesi Sosyal Bilimler Dergisi, 9, 71-93.

Kandemir, T., \& Karataş, H. (2016). Ticari bankaların finansal performanslarının çok kriterli karar verme yöntemleri ile incelenmesi: Borsa İstanbul'da işlem gören bankalar üzerine bir uygulama (2004-2014). Insan ve Toplum Bilimleri Araştırmaları Dergisi, 5(7), 1766- 1776.

Karaca, T. (2011). Proje Yönetiminde Çok Kriterli Karar Verme Tekniklerini Kullanarak Kritik Yolun Belirlenmesi, Yayımlanmamış Yüksek Lisans Tezi, Gazi Üniversitesi Fen Bilimleri Enstitüsü, Ankara.

Kaynak, E., Küçükemiroglu, O., \& Odabasi, Y. (1991). Commercial bank selection in Turkey. International Journal of Bank Marketing, 9(4), 30-39

Kennington, C., Hill, J., \& Rakowska, A. (1996). Consumer selection criteria for banks in Poland. International Journal of Bank Marketing, 14(4), 12-21.

Keršuliene, V., Kazimireas, Z., \& Turskis, Z. (2010). Selection of rational dispute resolution method by applying new stepwise weight assessment ratio analysis (SWARA). Journal of Business Economics and Management, 11(2), 243-258.

Khazeh, K., \& Decker, W. H. (1992). How customer choose banks?. The Journal of Retail Banking, 14(4), 41-44.

Kılıç, S. B. (2006). Türk bankacılık sistemi için çok kriterli karar alma analizine dayalı bir erken uyarı modelinin tahmini. Orta Doğu Teknik Üniversitesi Gelişme Dergisi, $33,117-154$.

Kosmidou, K., \& Zopounidis, C. (2008). Measurement of bank performance in Greece. South-Eastern Europe Journal of Economics, 1, 79- 95.

Lam, R. \& Burton, S. (2005). Bank selection and share of wallet among SMEs: Apparent differences between Hong
Kong and Australia. Journal of Financial Services Marketing, 9(3), 204-213.

Lariviere, B., \& Poel, D. V. (2007). Banking behaviour after the lifecycle event of "moving in together": An exploratory study of the role of marketing investments. European Journal of Operational Research, 183(1), 345-369.

Metawa, S. A., \& Almossawi, M. (1998). Banking behavior of Islamic bank customers: Perspectives and implications. International Journal of Banking Marketing, 16(7), 299313.

Mokhlis, S. (2009). Determinants of choice criteria in Malaysia's retail banking: An analysis of gender-based choice decisions. European Journal of Economics, Finance and Administrative Sciences, 2(16), 18-30.

Nielson, F. J., Terry, C., \& Trayler, R. M. (1998). Business banking in Australia: a comparison of expectations, International Journal of Bank Marketing, 16(6), 253-263.

Owusu-Frimpong, N. (1999). Patronage behaviour of Ghanaian bank customers. International Journal of Bank Marketing, 7(17), 335-342.

Ömürbek, N., \& Aksoy, E. (2016). Bir petrol şirketinin çok kriterli karar verme teknikleri ile performans değerlendirmesi. Süleyman Demirel Üniversitesi İktisadi ve İdari Bilimler Fakültesi Dergisi, 21(3), 723-756.

Ömürbek, N., Karaatlı, M., Eren, H., \& Şanlı, B. (2014). AHP temelli PROMETHEE siralama yöntemleri ile hafif ticari araç seçimi. Süleyman Demirel Üniversitesi Iktisadi ve İdari Bilimler Fakültesi Dergisi, 19(4), 47-64.

Önay, O., \& Çetin, E. (2012). Turistik yerlerin popülaritesinin belirlenmesi: İstanbul örneği. Yönetim Dergisi, 23(72), 90109.

Özbek, A. (2017). Çok kriterli karar verme yöntemleri ve excel ile problem çözümü. Ankara: Seçkin Akademik ve Mesleki Yayınları.

Özcan, A., \& Ömürbek, N. (2016). BİST’de işlem gören sigorta şirketlerinin MULTIMOORA yöntemiyle performans ölçümü. Uluslararası Işsletme, Ekonomi ve Yönetim Perspektifleri Dergisi, 1(2), 64-75.

Özsoy, İ., Görmez, B., \& Mekik, S. (2013). Türkiye'de katılım bankalarının tercih edilme sebepleri: Ampirik bir tetkik. Yönetim ve Ekonomi Dergisi, 20(1), 187-206

Ravi, V., Kurniawan, H., Thai, P. N. K., \& Kumar, P. R. (2008). Soft computing system for bank performance prediction. Applied Soft Computing, 8, 305-315.

Ruzgyz, A., Volvaciovas, R., Ignatavicius, C., \& Turskis, Z. (2014). Integrated evaluation of external Wall insulation in residential buildings using SWARA-TODIM MCDM method. Journal of Civil Engineering and management, 20(1), 103-110.

Sakarya, Ş., \& Aytekin, S. (2013). İMKB'de işlem gören mevduat bankalarının performansları ile hisse senedi getirileri arasındaki ilişkinin ölçülmesi: PROMETHEE çok kriterli karar verme yöntemiyle bir uygulama. Uluslararası Alanya Işletme Fakültesi Dergisi, 5(2), 99-109.

Stanujkic, D., Karabasevic, D., \& Zavadskas, E. K. (2015). A framework for the selection of a packaging design based 
on the SWARA method. Inzinerine Ekonomika Engineering Economics, 26(2), 181-187.

Taşabat, S. E., Cinemre, N., \& Şen, S. (2015). Farklı ağırlıklandırma tekniklerinin denendiği çok kriterli karar verme yöntemleri ile Türkiye'deki mevduat bankalarının mali performanslarının değerlendirilmesi. Sosyal Bilimler Araştırma Dergisi, 4(2), 96-110.

Taşkın, C.., Akat, Ö., \& Erol, Z. (2010). Tüketicilerin Banka Tercihini Etkileyen Faktörlerin Belirlenmesi: Bursa'da bir araştırma. Anadolu Üniversitesi Sosyal Bilimler Dergisi, 10(3), 11-22.

Tezergil, S. A. (2016). VIKOR yöntemi ile Türk bankacılık sektörünün performans analizi. Marmara Üniversitesi İktisadi ve İdari Bilimler Dergisi, 38(1), 357-373.

Türkyılmaz, A., \& Özkan, C. (2005, Haziran). Ulusal müşteri memnuniyeti indeksleri. Kalder Forum, 16, 73-74.

Wel, C., \& Nor, S. (2003). The influences of personal and sociological factors on consumer bank selection decision in Malaysia. Journal of American Academy of Business, 1(2), 399-404.

Wu, H. Y., Tzeng, G. H., \& Chen, Y. H. (2009). A fuzzy MCDM approach for evaluating banking performance based on balanced scorecard. Expert Systems with Applications, 36(6), 10135-10147.

Yayar, R., \& Baykara, H. (2012). TOPSIS yöntemi ile katılım bankalarının etkinliği ve verimliliği üzerine bir uygulama. İsletme ve Ekonomi Araştırmaları Dergisi, 3(4), 21-42.
Yıldırım B. F., \& Önder, E. (2015). Çok Kriterli Karar Verme Yöntemleri. Bursa: Dora Yayınları.

Yıldırım, B. F., \& Önay, O. (2013). Bulut teknolojisi firmalarının bulanık AHP-MOORA yöntemi kullanılarak sıralanması. I. $\ddot{U}$. Işsletme Fakültesi Işsletme İktisadi Enstitüsü Yönetim Dergisi, 24(75), 60-81.

Yılmaz, V., Çelik, H. E., \& Depren, B. (2007). Devlet ve özel sektör bankalardaki hizmet kalitesinin karşılaştırılması: Eskişehir örneği. Doğuş Üniversitesi Dergisi, 8(2), 234248.

Yue, H., \& Tom, G. (1995). How the Chinese Select their banks. Journal of Retail Banking, 16(4), 36-39.

Yurdoğlu, H., \& Kundakc1, N. (2017). SWARA ve WASPAS yöntemleri ile sunucu seçimi. Balıkesir Üniversitesi Sosyal Bilimler Enstitüsü Dergisi, 20(38), 253-269.

Yükçü, S., \& Kaplanoğlu, E. (2015). Çok kriterli karar verme yöntemleriyle gözaltı pazarı şirketlerinin finansal performanslarının belirlenmesi. Muhasebe Bilim Dünyası Dergisi, 17(3): 587-616.

Zineldin, M. (1996). Bank Strategic Positioning and Some Determinants of Bank Selection. International Journal of Bank Marketing, 14(6), 12-22.

Zolfani, S. H., Zavadskas, E. K., \& Turskis, Z. (2013). Design of products with both International and Local perspectives based on Yin-Yang balance theory and SWARA method. Economic Research - Ekonomska Istrazivanja, 26(2), 153166. 
Ekler

Ek 1. Karar Verici Bazında Ana Kriterlerin Önem Derecesine Göre Sıralanması

\begin{tabular}{|c|c|c|c|c|c|c|c|c|c|c|}
\hline Kriterler $\quad$ Karar Verici & KV1 & KV2 & KV3 & KV4 & KV5 & KV6 & KV7 & KV8 & KV9 & KV10 \\
\hline C1 Bankanın Fiziki Özellikleri ve Teknik Yapısı & 4 & 5 & 8 & 5 & 1 & 6 & 7 & 8 & 8 & 5 \\
\hline C2 Banka Personelinin Özellikleri & 7 & 7 & 5 & 7 & 8 & 5 & 3 & 7 & 7 & 8 \\
\hline C3 İşlem Kolaylığg ve Maliyeti & 2 & 4 & 3 & 1 & 7 & 1 & 1 & 1 & 2 & 4 \\
\hline C4 Ürün ve Hizmet Çeşitliliği & 6 & 8 & 6 & 8 & 6 & 8 & 5 & 4 & 6 & 6 \\
\hline C5 Bankanın Güvenilirliği & 1 & 2 & 1 & 2 & 5 & 7 & 2 & 3 & 1 & 1 \\
\hline C6 Erişim Kolaylığ1 & 3 & 3 & 4 & 3 & 4 & 4 & 4 & 2 & 5 & 2 \\
\hline C7 Bankanın İmaj1/İtibarı & 5 & 1 & 2 & 6 & 3 & 3 & 6 & 5 & 3 & 3 \\
\hline C8 Kuruma Bağlilık & 8 & 6 & 7 & 4 & 2 & 2 & 8 & 6 & 4 & 7 \\
\hline
\end{tabular}

Ek 2. Karar Verici Bazında Alt Kriterlerin Önem Derecesine Göre Siralanması

\begin{tabular}{|c|c|c|c|c|c|c|c|c|c|c|c|}
\hline \multirow{4}{*}{$\begin{array}{l}\text { Fiziki Öz. ve Teknik } \\
\text { Yapıs1 }\end{array}$} & Kriter & KV1 & KV2 & KV3 & KV4 & KV5 & KV6 & KV7 & KV8 & \multicolumn{2}{|c|}{ KV9 KV10 } \\
\hline & C1.1 Bankanın finansal gücü & 1 & 2 & 1 & 1 & 3 & 1 & 1 & 1 & 1 & 2 \\
\hline & C1.2 Bankanın iç-dış görünümü & 3 & 3 & 3 & 3 & 2 & 3 & 3 & 3 & 3 & 3 \\
\hline & C1.3 Bankanın teknolojik altyapısı & 2 & 1 & 2 & 2 & 1 & 2 & 2 & 2 & 2 & 1 \\
\hline \multirow{4}{*}{ Banka Personelinin Öz. } & $\begin{array}{l}\text { C2.1 Personeli bilgili ve konusuna } \\
\text { vakıf olmas1 }\end{array}$ & 1 & 2 & 4 & 1 & 4 & 2 & 1 & 2 & 1 & 4 \\
\hline & $\begin{array}{l}\text { C2.2 Personelin işlemleri hızlı ve } \\
\text { doğru sonuçlandırması }\end{array}$ & 2 & 1 & 3 & 2 & 1 & 1 & 2 & 1 & 3 & 3 \\
\hline & $\begin{array}{l}\text { C2.3 Personelin yol gösterici ve } \\
\text { yardımsever olması }\end{array}$ & 4 & 3 & 2 & 3 & 2 & 3 & 3 & 3 & 2 & 1 \\
\hline & $\begin{array}{l}\text { C2.4 Personelin iyi müşteri ilişkileri } \\
\text { ve bağlantıları }\end{array}$ & 3 & 4 & 1 & 4 & 3 & 4 & 4 & 4 & 4 & 2 \\
\hline \multirow{4}{*}{$\begin{array}{l}\text { İşlem Kolaylığı ve } \\
\text { Maliyeti }\end{array}$} & C3.1 Kredi kullanma kolaylığ 1 & 3 & 2 & 1 & 1 & 1 & 3 & 3 & 1 & 1 & 2 \\
\hline & C3.2 Bürokratik işlemlerin az olması & 2 & 3 & 3 & 3 & 3 & 1 & 2 & 3 & 3 & 3 \\
\hline & $\begin{array}{l}\text { C3.3 Yapılan işlemlerden düşük } \\
\text { masraf alınması }\end{array}$ & 1 & 1 & 2 & 2 & 2 & 2 & 1 & 2 & 2 & 1 \\
\hline & C3.4 Verilen faizin yüksek olmas1 & 4 & 4 & 4 & 4 & 4 & 4 & 4 & 4 & 4 & 4 \\
\hline \multirow{4}{*}{$\begin{array}{l}\text { Ürün ve Hizmet } \\
\text { Çeşitliliği }\end{array}$} & C4.1 Kredi olanaklarının çeşitliliği & 3 & 2 & 1 & 1 & 1 & 3 & 1 & 1 & 2 & 2 \\
\hline & C4.2 çek defteri vermesi & 2 & 3 & 3 & 2 & 4 & 2 & 2 & 4 & 4 & 3 \\
\hline & $\begin{array}{l}\text { C4.3 finansal danışmanlık hizmeti } \\
\text { sağlanması }\end{array}$ & 1 & 1 & 2 & 3 & 2 & 1 & 3 & 3 & 1 & 1 \\
\hline & $\begin{array}{l}\text { C4.4 Değişen pazar ihtiyaçlarına } \\
\text { yönelik yeni ürünlerin sunulamaması }\end{array}$ & 4 & 4 & 4 & 4 & 3 & 4 & 4 & 2 & 3 & 4 \\
\hline \multirow{5}{*}{ Bankanın Güvenilirliği } & C5.1 Kişisel bilgilerin saklanması & 1 & 2 & 3 & 1 & 4 & 4 & 1 & 2 & 2 & 3 \\
\hline & $\begin{array}{l}\text { C5.2 Bankanın uzun zamanadır } \\
\text { faaliyette bulunması }\end{array}$ & 3 & 3 & 2 & 4 & 2 & 2 & 3 & 1 & 3 & 2 \\
\hline & C5.3 Bankanın tavsiye edilmesi & 4 & 4 & 4 & 3 & 3 & 3 & 2 & 5 & 4 & 4 \\
\hline & \begin{tabular}{|l|} 
C5.4Devlet bankas1 olmas1 \\
\end{tabular} & 2 & 5 & 1 & 2 & 1 & 1 & 4 & 4 & 1 & 1 \\
\hline & $\begin{array}{l}\text { C5.5 Sürekli hatalı işlemlerle } \\
\text { karşılaşılması }\end{array}$ & 5 & 1 & 5 & 5 & 5 & 5 & 5 & 3 & 5 & 5 \\
\hline \multirow[b]{2}{*}{ Erişim Kolaylığ 1} & C6.1 Bankanın uygun yerleşim yeri & 1 & 1 & 1 & 1 & 1 & 1 & 1 & 1 & 1 & 1 \\
\hline & $\begin{array}{l}\text { C6.2 Bankanın üst düzey } \\
\text { yöneticilerine ulaşma zorluğu }\end{array}$ & 2 & 2 & 2 & 2 & 2 & 2 & 2 & 2 & 2 & 2 \\
\hline \multirow{3}{*}{ Bankanın İmajı/ İtibarı } & C7.1 Bankanın tanınmışlığı & 1 & 3 & 1 & 1 & 1 & 1 & 1 & 1 & 1 & 3 \\
\hline & C7.2 Çevre dostu olması & 3 & 2 & 3 & 2 & 3 & 2 & 3 & 3 & 3 & 2 \\
\hline & $\begin{array}{l}\text { C7.3 Bankanın toplumsal konulara } \\
\text { hassasiyeti }\end{array}$ & 2 & 1 & 2 & 3 & 2 & 3 & 2 & 2 & 2 & 1 \\
\hline \multirow{4}{*}{ Kuruma Bağl11ık } & $\begin{array}{l}\text { C8.1 Bankanın sunduğu hizmet } \\
\text { kalitesinin sürekliliği }\end{array}$ & 1 & 1 & 1 & 1 & 1 & 1 & 1 & 1 & 1 & 1 \\
\hline & $\begin{array}{l}\text { C8.2 Bankanın müşterilerine kişisel } \\
\text { ilgi göstermesi }\end{array}$ & 2 & 2 & 3 & 2 & 2 & 3 & 2 & 2 & 2 & 2 \\
\hline & C8.3 Katılım (faizsiz) bankası olmas1 & 3 & 4 & 2 & 4 & 3 & 4 & 3 & 3 & 3 & 3 \\
\hline & $\begin{array}{l}\text { C8.4 Personelin eş dost, tanıdık, } \\
\text { akraba olması }\end{array}$ & 4 & 3 & 4 & 3 & 4 & 2 & 4 & 4 & 4 & 4 \\
\hline
\end{tabular}


Ek 3. Karar Vericilere Göre Ana Kriterlerin Karşılaştırmalı Önemi

\begin{tabular}{|c|c|c|c|c|c|c|c|c|c|c|c|c|c|c|c|c|c|c|c|c|}
\hline \multirow{2}{*}{$\begin{array}{l}\text { Önem } \\
\text { Sırası }\end{array}$} & \multicolumn{2}{|c|}{ KV1 } & \multicolumn{2}{|c|}{ KV2 } & \multicolumn{2}{|c|}{ KV3 } & \multicolumn{2}{|c|}{ KV4 } & \multicolumn{2}{|c|}{ KV5 } & \multicolumn{2}{|c|}{ KV6 } & \multicolumn{2}{|c|}{ KV7 } & \multicolumn{2}{|c|}{ KV8 } & \multicolumn{2}{|c|}{ KV9 } & \multicolumn{2}{|c|}{ KV10 } \\
\hline & Sira & $s_{j}$ & Sira & $s_{j}$ & Sira & $s_{j}$ & Sira & $s_{j}$ & Sira & $s_{j}$ & Sura & $s_{j}$ & Sura & $s_{j}$ & Sira & $s_{j}$ & Sira & $s_{j}$ & Sura & $s_{j}$ \\
\hline 1 & $\mathrm{C} 5$ & & & & & & & & $\mathrm{C} 1$ & & & & $\mathrm{C} 3$ & & $\mathrm{C} 3$ & & & & & \\
\hline 2 & & 0,30 & & 0,20 & & 0,60 & & 0,50 & $C c$ & 0,90 & 40 & 0,40 & (J) & 0,30 & $c 0$ & 0,60 & $\mathrm{C} 3$ & 0,80 & C6 & 0,90 \\
\hline 3 & & 20 & & & & & & 1,00 & & 0,80 & & 0,20 & & & & 0,10 & & 0,50 & & 0,90 \\
\hline 4 & & & & & & & & 1,00 & & 0,70 & & & & & & 0,80 & & 0,50 & & 0,80 \\
\hline 5 & & 0,20 & & 0,40 & & 0,70 & $\mathrm{C} 1$ & 1,00 & $\mathrm{C}$ & 1,00 & C? & 0,40 & & 0,20 & $\mathrm{C} 7$ & 0,75 & C6 & 0,70 & & 0,90 \\
\hline 6 & $C$ & 0,30 & & 0,30 & $\mathrm{C} 4$ & 0,60 & C7 & 1,00 & $\mathrm{C} 4$ & 1,00 & $\mathrm{C} 1$ & 0,30 & $\mathrm{C} 7$ & 0,50 & $\mathrm{C} 8$ & 0,45 & $\mathrm{C} 4$ & 0,70 & $\mathrm{C} 4$ & 0,80 \\
\hline 7 & & & & 0,20 & & 0,75 & $\mathrm{C} 2$ & 1,00 & $\mathrm{C} 3$ & 0,90 & C5 & 0,30 & & & & 0,65 & & 0,90 & & 0,70 \\
\hline 8 & $\mathrm{C} 8$ & 0,30 & $\mathrm{C} 4$ & 0,40 & $\mathrm{C} 1$ & 0,80 & $\mathrm{C} 4$ & 1,00 & $\mathrm{C} 2$ & 0,90 & $\mathrm{C} 4$ & 0,40 & $\mathrm{C} 8$ & 0,15 & $\mathrm{C} 1$ & 0,85 & $\mathrm{C} 1$ & 0,20 & $\mathrm{C} 2$ & 0,90 \\
\hline
\end{tabular}

Ek 4. Karar Vericilere Göre Alt Kriterlerin Karşılaştırmalı Önemi

\begin{tabular}{|c|c|c|c|c|c|c|c|c|c|c|c|c|c|c|c|c|c|c|c|c|c|}
\hline & \multirow{2}{*}{$\begin{array}{l}\text { Önem } \\
\text { Surası }\end{array}$} & \multicolumn{2}{|c|}{ KV1 } & \multicolumn{2}{|c|}{ KV2 } & \multicolumn{2}{|c|}{ KV3 } & \multicolumn{2}{|c|}{ KV4 } & \multicolumn{2}{|c|}{ KV5 } & \multicolumn{2}{|c|}{ KV6 } & \multicolumn{2}{|c|}{ KV7 } & \multicolumn{2}{|c|}{ KV8 } & \multicolumn{2}{|c|}{ KV9 } & \multicolumn{2}{|c|}{ KV10 } \\
\hline & & Sira & $s_{j}$ & Sura & $s_{j}$ & Sira & $s_{j}$ & Sira & $s_{j}$ & Sura & $s_{j}$ & Sura & $s_{j}$ & Sura & $s_{j}$ & Sura & $s_{j}$ & Sira & $s_{j}$ & Sira & $s_{j}$ \\
\hline \multirow{3}{*}{$\begin{array}{c}\text { Fiziki Öz. } \\
\text { ve Teknik } \\
\text { Yapı }\end{array}$} & 1 & C1.1 & & C3 & $\rightarrow$ & $\mathrm{C} 1$ & & $\mathrm{C} 1$ & 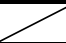 & C3 & & $\mathrm{C} 1$ & 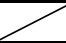 & $\mathrm{C} 1$ & & $\mathrm{C} 1$ & & $\mathrm{C} 1$ & & C3 & \\
\hline & 2 & C1.3 & 0,30 & $\mathrm{C} 1$ & 0,50 & $\mathrm{C} 3$ & 0,80 & $\mathrm{C} 3$ & 1,00 & $\mathrm{C} 2$ & 1,00 & $\mathrm{C} 3$ & 0,40 & $\mathrm{C} 3$ & 0,90 & $\mathrm{C} 3$ & 0,90 & $\mathrm{C} 3$ & 0,90 & $\mathrm{C} 1$ & 0,90 \\
\hline & 3 & C1.2 & 0,30 & $\mathrm{C} 2$ & 0,15 & $\mathrm{C} 2$ & 0,75 & $\mathrm{C} 2$ & 1,00 & $\mathrm{C} 1$ & 0,50 & $\mathrm{C} 2$ & 0,40 & $\mathrm{C} 2$ & 0,90 & $\mathrm{C} 2$ & 0,90 & $\mathrm{C} 2$ & 0,90 & $\mathrm{C} 2$ & 0,90 \\
\hline \multirow{4}{*}{$\begin{array}{c}\text { Personel } \\
O ̈ z .\end{array}$} & 1 & $\mathrm{C} 2.1$ & 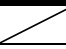 & $\mathrm{C} 2$ & 7 & $\mathrm{C} 4$ & 1 & $\mathrm{C} 1$ & 1 & $\mathrm{C} 2$ & 1 & $\mathrm{C} 2$ & 1 & $\mathrm{C} 1$ & 7 & $\mathrm{C} 2$ & 1 & $\mathrm{C} 1$ & 7 & $\mathrm{C} 3$ & 1 \\
\hline & 2 & $\mathrm{C} 2.2$ & 0,55 & $\mathrm{C} 1$ & 0,15 & $\mathrm{C} 3$ & 0,50 & $\mathrm{C} 2$ & 0,80 & $\mathrm{C} 3$ & 1,00 & $\mathrm{C} 1$ & 0,40 & $\mathrm{C} 2$ & 0,10 & $\mathrm{C} 1$ & 0,85 & $\mathrm{C} 3$ & 0,80 & $\mathrm{C} 4$ & 0,90 \\
\hline & 3 & $\mathrm{C} 2.4$ & 0,50 & $\mathrm{C} 3$ & 0,40 & $\mathrm{C} 2$ & 0,50 & $\mathrm{C} 3$ & 0,90 & $\mathrm{C} 4$ & 0,80 & $\mathrm{C} 3$ & 0,40 & $\mathrm{C} 3$ & 0,60 & $\mathrm{C} 3$ & 0,60 & $\mathrm{C} 2$ & 0,70 & $\mathrm{C} 2$ & 0,90 \\
\hline & 4 & $\mathrm{C} 2.3$ & 0,55 & $\mathrm{C} 4$ & 0,15 & $\mathrm{C} 1$ & 0,50 & $\mathrm{C} 4$ & 0,70 & $\mathrm{C} 1$ & 0,70 & $\mathrm{C} 4$ & 0,40 & $\mathrm{C} 4$ & 0,60 & $\mathrm{C} 4$ & 0,55 & $\mathrm{C} 4$ & 0,90 & $\mathrm{C} 1$ & 0,90 \\
\hline \multirow{4}{*}{$\begin{array}{c}\text { İşlem } \\
\text { Kolaylı̆̆ } \\
\text { ve Maliyet }\end{array}$} & 1 & C 3.3 & & C3 & & $\mathrm{C} 1$ & & $\mathrm{C} 1$ & & $\mathrm{C} 1$ & $\gamma$ & $\mathrm{C} 2$ & 7 & $\mathrm{C} 3$ & $\gamma$ & $\mathrm{C} 1$ & 1 & $\mathrm{C} 1$ & $\gamma$ & $\mathrm{C} 3$ & 7 \\
\hline & 2 & C3.2 & 0,55 & $\mathrm{C} 1$ & 0,20 & $\mathrm{C} 3$ & 0,95 & $\mathrm{C} 3$ & 0,80 & $\mathrm{C} 3$ & 0,50 & $\mathrm{C} 3$ & 0,50 & $\mathrm{C} 2$ & 0,90 & $\mathrm{C} 3$ & 0,65 & $\mathrm{C} 3$ & 0,90 & $\mathrm{C} 1$ & 0,90 \\
\hline & 3 & C3.1 & 0,50 & $\mathrm{C} 2$ & 0,35 & $\mathrm{C} 2$ & 0,85 & $\mathrm{C} 2$ & 0,90 & $\mathrm{C} 2$ & 0,80 & $\mathrm{C} 1$ & 0,50 & $\mathrm{C} 1$ & 0,50 & $\mathrm{C} 2$ & 0,75 & $\mathrm{C} 2$ & 0,30 & $\mathrm{C} 2$ & 0,90 \\
\hline & 4 & C3.4 & 0,45 & $\mathrm{C} 4$ & 0,10 & $\mathrm{C} 4$ & 0,95 & $\mathrm{C} 4$ & 0,50 & $\mathrm{C} 4$ & 0,50 & $\mathrm{C} 4$ & 0,40 & $\mathrm{C} 4$ & 0,90 & $\mathrm{C} 4$ & 0,80 & $\mathrm{C} 4$ & 0,20 & $\mathrm{C} 4$ & 0,10 \\
\hline \multirow{4}{*}{$\begin{array}{c}\text { Ürün ve } \\
\text { Hizmet } \\
\text { Çeşitliliği }\end{array}$} & 1 & $\mathrm{C} 4.3$ & 1 & $\mathrm{C} 3$ & 1 & $\mathrm{C} 1$ & 7 & $\mathrm{C} 1$ & 1 & $\mathrm{C} 1$ & 1 & $\mathrm{C} 3$ & 1 & $\mathrm{C} 1$ & 1 & $\mathrm{C} 1$ & 1 & $\mathrm{C} 3$ & 1 & $\mathrm{C} 3$ & $\angle$ \\
\hline & 2 & C4.2 & 0,55 & $\mathrm{C} 1$ & 0,50 & $\mathrm{C} 3$ & 0,65 & $\mathrm{C} 2$ & 0,80 & $\mathrm{C} 3$ & 0,80 & $\mathrm{C} 2$ & 0,40 & $\mathrm{C} 2$ & 0,80 & $\mathrm{C} 4$ & 0,80 & $\mathrm{C} 1$ & 0,20 & $\mathrm{C} 1$ & 0,80 \\
\hline & 3 & $\mathrm{C} 4.1$ & 0,40 & $\mathrm{C} 2$ & 0,25 & $\mathrm{C} 2$ & 0,70 & $\mathrm{C} 3$ & 0,90 & $\mathrm{C} 4$ & 0,70 & $\mathrm{C} 1$ & 0,40 & $\mathrm{C} 3$ & 0,70 & $\mathrm{C} 3$ & 0,65 & $\mathrm{C} 4$ & 0,70 & $\mathrm{C} 2$ & 0,70 \\
\hline & 4 & C4.4 & 0,70 & $\mathrm{C} 4$ & 0,15 & $\mathrm{C} 4$ & 0,80 & $\mathrm{C} 4$ & 1,00 & $\mathrm{C} 2$ & 0,50 & $\mathrm{C} 4$ & 0,40 & $\mathrm{C} 4$ & 0,90 & $\mathrm{C} 2$ & 0,90 & $\mathrm{C} 2$ & 0,80 & $\mathrm{C} 4$ & 0,90 \\
\hline \multirow{5}{*}{$\begin{array}{c}\text { Bankanın } \\
\text { Güvenilirli } \\
\check{g} i\end{array}$} & 1 & C5.1 & 1 & $\mathrm{C} 5$ & 7 & $\mathrm{C} 4$ & 4 & $\mathrm{C} 1$ & 7 & $\mathrm{C} 4$ & 7 & $\mathrm{C} 4$ & 1 & $\mathrm{C} 1$ & 1 & $\mathrm{C} 2$ & 1 & $\mathrm{C} 4$ & 7 & $\mathrm{C} 4$ & 7 \\
\hline & 2 & C5.4 & 0,60 & $\mathrm{C} 1$ & 0,15 & $\mathrm{C} 2$ & 0,80 & $\mathrm{C} 4$ & 1,00 & $\mathrm{C} 2$ & 1,00 & $\mathrm{C} 2$ & 0,50 & $\mathrm{C} 3$ & 0,90 & $\mathrm{C} 1$ & 0,65 & $\mathrm{C} 1$ & 0,05 & $\mathrm{C} 2$ & 0,90 \\
\hline & 3 & C5.2 & 0,55 & $\mathrm{C} 2$ & 0,30 & $\mathrm{C} 1$ & 0,75 & $\mathrm{C} 3$ & 0,70 & $\mathrm{C} 3$ & 0,80 & $\mathrm{C} 3$ & 0,50 & $\mathrm{C} 2$ & 0,50 & $\mathrm{C} 5$ & 0,75 & $\mathrm{C} 2$ & 1,00 & $\mathrm{C} 1$ & 0,90 \\
\hline & 4 & C5.3 & 0,40 & C3 & 0,40 & $\mathrm{C} 3$ & 0,85 & $\mathrm{C} 2$ & 0,80 & $\mathrm{C} 1$ & 0,50 & $\mathrm{C} 1$ & 0,40 & $\mathrm{C} 4$ & 0,40 & $\mathrm{C} 4$ & 0,80 & $\mathrm{C} 3$ & 0,80 & $\mathrm{C} 3$ & 0,80 \\
\hline & 5 & C5.5 & 0,65 & $\mathrm{C} 4$ & 0,45 & $\mathrm{C} 5$ & 0,90 & C5 & 1,00 & C5 & 0,60 & $\mathrm{C} 5$ & 0,40 & C5 & 0,90 & C3 & 0,80 & C5 & 1,00 & $\mathrm{C} 5$ & 0,80 \\
\hline \multirow{2}{*}{$\begin{array}{c}\text { Erişim } \\
\text { Kolaylı̆ğ } \\
\end{array}$} & 1 & C6.1 & & $\mathrm{C} 1$ & & $\mathrm{C} 1$ & & $\mathrm{C} 1$ & & $\mathrm{C} 1$ & 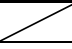 & $\mathrm{C} 1$ & & $\mathrm{C} 1$ & $z$ & $\mathrm{C} 1$ & 7 & $\mathrm{C} 1$ & 1 & $\mathrm{C} 1$ & $\angle$ \\
\hline & 2 & C6.2 & 0,65 & $\mathrm{C} 2$ & 0,50 & $\mathrm{C} 2$ & 0,90 & $\mathrm{C} 2$ & 1,00 & $\mathrm{C} 2$ & 1,00 & $\mathrm{C} 2$ & 0,50 & $\mathrm{C} 2$ & 0,90 & $\mathrm{C} 2$ & 0,80 & $\mathrm{C} 2$ & 0,35 & $\mathrm{C} 2$ & 0,90 \\
\hline \multirow{3}{*}{$\begin{array}{l}\text { İmajı } \\
\text { /Itibarl }\end{array}$} & 1 & C7.1 & 1 & $\mathrm{C} 3$ & 1 & $\mathrm{C} 1$ & 1 & $\mathrm{C} 1$ & 1 & $\mathrm{C} 1$ & 1 & $\mathrm{C} 1$ & 1 & $\mathrm{C} 1$ & 1 & $\mathrm{C} 1$ & 1 & $\mathrm{C} 1$ & 1 & $\mathrm{C} 3$ & 1 \\
\hline & 2 & C7.3 & 0,45 & $\mathrm{C} 2$ & 0,25 & $\mathrm{C} 3$ & 0,70 & $\mathrm{C} 2$ & 0,90 & $\mathrm{C} 3$ & 0,80 & $\mathrm{C} 2$ & 0,50 & $\mathrm{C} 3$ & 0,40 & $\mathrm{C} 3$ & 0,50 & $\mathrm{C} 3$ & 0,30 & $\mathrm{C} 2$ & 0,90 \\
\hline & 3 & C7.2 & 0,55 & $\mathrm{C} 1$ & 0,50 & $\mathrm{C} 2$ & 0,50 & C3 & 0,70 & $\mathrm{C} 2$ & 0,70 & $\mathrm{C} 3$ & 0,40 & $\mathrm{C} 2$ & 0,50 & $\mathrm{C} 2$ & 0,50 & $\mathrm{C} 2$ & 0,70 & $\mathrm{C} 1$ & 0,90 \\
\hline \multirow{4}{*}{$\begin{array}{l}\text { Kuruma } \\
\text { Bağlllık }\end{array}$} & 1 & $\mathrm{C} 8.1$ & 7 & $\mathrm{C} 1$ & 1 & $\mathrm{C} 1$ & 7 & $\mathrm{C} 1$ & 7 & $\mathrm{C} 1$ & 7 & $\mathrm{C} 1$ & 7 & $\mathrm{C} 1$ & 1 & $\mathrm{C} 1$ & 1 & $\mathrm{C} 1$ & 1 & $\mathrm{C} 1$ & 1 \\
\hline & 2 & C8.2 & 0,65 & $\mathrm{C} 2$ & 0,30 & $\mathrm{C} 3$ & 0,60 & $\mathrm{C} 2$ & 0,90 & $\mathrm{C} 2$ & 1,00 & $\mathrm{C} 4$ & 0,50 & $\mathrm{C} 2$ & 0,30 & $\mathrm{C} 2$ & 0,85 & $\mathrm{C} 2$ & 0,30 & $\mathrm{C} 2$ & 0,90 \\
\hline & 3 & C8.3 & 0,50 & $\mathrm{C} 4$ & 0,70 & $\mathrm{C} 2$ & 0,50 & $\mathrm{C} 4$ & 1,00 & $\mathrm{C} 3$ & 0,90 & $\mathrm{C} 2$ & 0,40 & $\mathrm{C} 3$ & 0,80 & $\mathrm{C} 3$ & 0,95 & $\mathrm{C} 3$ & 0,80 & $\mathrm{C} 3$ & 0,90 \\
\hline & 4 & C8.4 & 0,65 & C3 & 0,05 & C4 & 0,75 & C3 & 0,80 & $\mathrm{C} 4$ & 0,10 & C3 & 0,50 & C4 & 0,50 & C4 & 0,40 & C4 & 0,35 & $\mathrm{C} 4$ & 0,50 \\
\hline
\end{tabular}


Ek 5. Karar Verici 1'e Ait Ana Kriter Ağırlıklarını SWARA Yöntemi ile Hesaplama

\begin{tabular}{|c|c|c|c|c|c|}
\hline Sıralama & Kriterler & $\begin{array}{c}\text { Kriterin Bir Öncekine Göre } \\
\text { Karşılaştırmalı Önemi }\left(\boldsymbol{s}_{\boldsymbol{j}}\right)\end{array}$ & $\begin{array}{c}\text { Katsayı } \\
\left(\boldsymbol{k}_{\boldsymbol{j}}\right)\end{array}$ & $\begin{array}{c}\text { Önem Vektörüu } \\
\left(\boldsymbol{q}_{\boldsymbol{j}}\right)\end{array}$ & $\begin{array}{c}\text { Kriterlerin Göreceli } \\
\text { ĂğIIlıkları }\left(\boldsymbol{w}_{\boldsymbol{j}}\right)\end{array}$ \\
\hline 1 & $\mathrm{C} 5$ & 0,3 & 1,00 & 1,00 & 0,242 \\
\hline 2 & $\mathrm{C} 3$ & 0,2 & 1,30 & 0,77 & 0,186 \\
\hline 3 & $\mathrm{C} 6$ & 0,25 & 1,20 & 0,64 & 0,155 \\
\hline 4 & $\mathrm{C} 1$ & 0,2 & 1,25 & 0,51 & 0,124 \\
\hline 5 & $\mathrm{C} 7$ & 0,3 & 1,20 & 0,43 & 0,104 \\
\hline 6 & $\mathrm{C} 4$ & 0,3 & 1,30 & 0,33 & 0,080 \\
\hline 7 & $\mathrm{C} 2$ & 0,3 & 1,30 & 0,25 & 0,061 \\
\hline 8 & $\mathrm{C} 8$ & & 0,19 & 0,047 \\
\hline
\end{tabular}

Ek 6. Karar Verici 1'e Ait Alt Kriter Ağırlıklarını SWARA Yöntemi ile Hesaplama

\begin{tabular}{|c|c|c|c|c|c|c|}
\hline & Siralama & Kriterler & $s_{j}$ & $\boldsymbol{k}_{j}$ & $\boldsymbol{q}_{j}$ & $w_{j}$ \\
\hline \multirow{3}{*}{$\begin{array}{l}\text { Fiziki Öz. ve } \\
\text { Teknik Yapı }\end{array}$} & 1 & $\mathrm{C} 1.1$ & 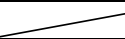 & 1,00 & 1,00 & 0,424 \\
\hline & 2 & C1.3 & 0,30 & 1,30 & 0,77 & 0,326 \\
\hline & 3 & $\mathrm{C} 1.2$ & 0,30 & 1,30 & 0,59 & 0,251 \\
\hline \multirow{4}{*}{ Personel $\ddot{O} z$. } & 1 & $\mathrm{C} 2.1$ & 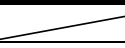 & 1,00 & 1,00 & 0,425 \\
\hline & 2 & $\mathrm{C} 2.2$ & 0,55 & 1,55 & 0,65 & 0,274 \\
\hline & 3 & C2.4 & 0,50 & 1,50 & 0,43 & 0,183 \\
\hline & 4 & C2.3 & 0,55 & 1,55 & 0,28 & 0,118 \\
\hline \multirow{4}{*}{$\begin{array}{c}\text { Isslem Kolayliğl ve } \\
\text { Maliyet }\end{array}$} & 1 & C3.3 & 2 & 1,00 & 1,00 & 0,422 \\
\hline & 2 & C3.2 & 0,55 & 1,55 & 0,65 & 0,272 \\
\hline & 3 & C3.1 & 0,50 & 1,50 & 0,43 & 0,181 \\
\hline & 4 & C3.4 & 0,45 & 1,45 & 0,30 & 0,125 \\
\hline \multirow{4}{*}{$\begin{array}{l}\text { Ürün ve Hizmet } \\
\text { Çeşitliliği }\end{array}$} & 1 & $\mathrm{C} 4.3$ & & 1,00 & 1,00 & 0,421 \\
\hline & 2 & $\mathrm{C} 4.2$ & 0,55 & 1,55 & 0,65 & 0,271 \\
\hline & 3 & $\mathrm{C} 4.1$ & 0,40 & 1,40 & 0,46 & 0,194 \\
\hline & 4 & $\mathrm{C} 4.4$ & 0,70 & 1,70 & 0,27 & 0,114 \\
\hline \multirow{5}{*}{$\begin{array}{c}\text { Bankanın } \\
\text { Güvenilirliği }\end{array}$} & 1 & C5.1 & 2 & 1,00 & 1,00 & 0,401 \\
\hline & 2 & $\mathrm{C} 5.4$ & 0,60 & 1,60 & 0,63 & 0,251 \\
\hline & 3 & C5.2 & 0,55 & 1,55 & 0,40 & 0,162 \\
\hline & 4 & C5.3 & 0,40 & 1,40 & 0,29 & 0,116 \\
\hline & 5 & C5.5 & 0,65 & 1,65 & 0,17 & 0,070 \\
\hline \multirow{2}{*}{ Erişim Kolaylığ } & 1 & C6.1 & & 1,00 & 1,00 & 0,623 \\
\hline & 2 & C6.2 & 0,65 & 1,65 & 0,61 & 0,377 \\
\hline \multirow{3}{*}{$\begin{array}{l}\dot{I m a j l} \\
\text { /İtibarl }\end{array}$} & 1 & C7.1 & 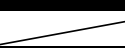 & 1,00 & 1,00 & 0,468 \\
\hline & 2 & C7.3 & 0,45 & 1,45 & 0,69 & 0,323 \\
\hline & 3 & $\mathrm{C} 7.2$ & 0,55 & 1,55 & 0,44 & 0,208 \\
\hline \multirow{4}{*}{ Kuruma Bağlılık } & 1 & C8.1 & & 1,00 & 1,00 & 0,443 \\
\hline & 2 & C8.2 & 0,65 & 1,65 & 0,61 & 0,269 \\
\hline & 3 & C8.3 & 0,50 & 1,50 & 0,40 & 0,179 \\
\hline & 4 & C8.4 & 0,65 & 1,65 & 0,24 & 0,109 \\
\hline
\end{tabular}


Ek 7. Ana Kriterlerin Her Karar Verici İçin Hesaplanan Ağırlıkları

\begin{tabular}{|c|c|c|c|c|c|c|c|c|c|c|}
\hline $\begin{array}{c}\text { Ana } \\
\text { Kriterler }\end{array}$ & KV1 & KV2 & KV3 & KV4 & KV5 & KV6 & KV7 & KV8 & KV9 & KV10 \\
\hline C1 & 0,124 & 0,087 & 0,014 & 0,036 & 0,499 & 0,072 & 0,033 & 0,014 & 0,015 & 0,038 \\
\hline C2 & 0,061 & 0,056 & 0,072 & 0,009 & 0,250 & 0,093 & 0,143 & 0,026 & 0,018 & 0,007 \\
\hline C3 & 0,186 & 0,122 & 0,147 & 0,430 & 0,131 & 0,264 & 0,335 & 0,341 & 0,223 & 0,072 \\
\hline C4 & 0,080 & 0,040 & 0,045 & 0,004 & 0,119 & 0,039 & 0,070 & 0,108 & 0,034 & 0,021 \\
\hline C5 & 0,242 & 0,219 & 0,353 & 0,287 & 0,499 & 0,055 & 0,258 & 0,194 & 0,402 & 0,471 \\
\hline C6 & 0,155 & 0,146 & 0,123 & 0,143 & 0,250 & 0,131 & 0,084 & 0,213 & 0,058 & 0,248 \\
\hline C7 & 0,104 & 0,263 & 0,221 & 0,018 & 0,131 & 0,157 & 0,047 & 0,062 & 0,149 & 0,130 \\
\hline C8 & 0,047 & 0,067 & 0,026 & 0,072 & 0,119 & 0,188 & 0,029 & 0,042 & 0,099 & 0,012 \\
\hline
\end{tabular}

Ek 8. Alt Kriterlerin Her Karar Verici İçin Hesaplanan Ağırlıkları

\begin{tabular}{|c|c|c|c|c|c|c|c|c|c|c|c|}
\hline & Alt Kriter & KV1 & KV2 & KV3 & KV4 & KV5 & KV6 & KV7 & KV8 & KV9 & KV10 \\
\hline \multirow{3}{*}{$\begin{array}{l}\text { Fiziki Öz. } \\
\text { Teknik Yps }\end{array}$} & C1.1 & 0,424 & 0,297 & 0,534 & 0,571 & 0,182 & 0,450 & 0,555 & 0,555 & 0,555 & 0,292 \\
\hline & $\mathrm{C} 1.2$ & 0,251 & 0,258 & 0,169 & 0,143 & 0,273 & 0,229 & 0,154 & 0,154 & 0,154 & 0,154 \\
\hline & $\mathrm{C} 1.3$ & 0,326 & 0,445 & 0,297 & 0,286 & 0,545 & 0,321 & 0,292 & 0,292 & 0,292 & 0,555 \\
\hline \multirow{4}{*}{$\begin{array}{c}\text { Banka } \\
\text { Personelinin Öz. }\end{array}$} & $\mathrm{C} 2.1$ & 0,425 & 0,287 & 0,123 & 0,495 & 0,084 & 0,276 & 0,353 & 0,258 & 0,487 & 0,075 \\
\hline & $\mathrm{C} 2.2$ & 0,274 & 0,330 & 0,185 & 0,275 & 0,515 & 0,386 & 0,321 & 0,477 & 0,159 & 0,142 \\
\hline & $\mathrm{C} 2.3$ & 0,118 & 0,205 & 0,277 & 0,145 & 0,258 & 0,197 & 0,201 & 0,161 & 0,270 & 0,513 \\
\hline & $\mathrm{C} 2.4$ & 0,183 & 0,178 & 0,415 & 0,085 & 0,143 & 0,141 & 0,125 & 0,104 & 0,084 & 0,270 \\
\hline \multirow{4}{*}{$\begin{array}{l}\text { İşlem Kolaylığı } \\
\text { ve Maliyeti }\end{array}$} & $\mathrm{C} 3.1$ & 0,181 & 0,277 & 0,518 & 0,490 & 0,438 & 0,183 & 0,170 & 0,466 & 0,441 & 0,256 \\
\hline & $\mathrm{C} 3.2$ & 0,272 & 0,205 & 0,143 & 0,143 & 0,162 & 0,412 & 0,255 & 0,161 & 0,178 & 0,135 \\
\hline & C3.3 & 0,422 & 0,332 & 0,265 & 0,272 & 0,292 & 0,275 & 0,485 & 0,283 & 0,232 & 0,487 \\
\hline & C3.4 & 0,125 & 0,186 & 0,074 & 0,095 & 0,108 & 0,131 & 0,090 & 0,090 & 0,149 & 0,123 \\
\hline \multirow{4}{*}{$\begin{array}{l}\text { Ürün ve Hizmet } \\
\text { Çeşitliliği }\end{array}$} & $\mathrm{C} 4.1$ & 0,194 & 0,250 & 0,463 & 0,501 & 0,476 & 0,197 & 0,487 & 0,483 & 0,321 & 0,270 \\
\hline & $\mathrm{C} 4.2$ & 0,271 & 0,200 & 0,165 & 0,279 & 0,104 & 0,276 & 0,270 & 0,086 & 0,105 & 0,159 \\
\hline & C4.3 & 0,421 & 0,375 & 0,281 & 0,147 & 0,265 & 0,386 & 0,159 & 0,163 & 0,385 & 0,487 \\
\hline & $\mathrm{C} 4.4$ & 0,114 & 0,174 & 0,092 & 0,073 & 0,156 & 0,141 & 0,084 & 0,268 & 0,189 & 0,084 \\
\hline \multirow{5}{*}{$\begin{array}{c}\text { Bankanın } \\
\text { Güvenilirliği }\end{array}$} & C5.1 & 0,401 & 0,260 & 0,149 & 0,490 & 0,089 & 0,120 & 0,443 & 0,269 & 0,337 & 0,136 \\
\hline & C5.2 & 0,162 & 0,200 & 0,260 & 0,080 & 0,241 & 0,251 & 0,155 & 0,444 & 0,169 & 0,258 \\
\hline & C5.3 & 0,116 & 0,143 & 0,080 & 0,144 & 0,134 & 0,167 & 0,233 & 0,047 & 0,094 & 0,075 \\
\hline & C5.4 & 0,251 & 0,098 & 0,468 & 0,245 & 0,481 & 0,377 & 0,111 & 0,085 & 0,354 & 0,490 \\
\hline & $\mathrm{C} 5.5$ & 0,070 & 0,299 & 0,042 & 0,040 & 0,056 & 0,085 & 0,058 & 0,154 & 0,047 & 0,042 \\
\hline \multirow{2}{*}{ Erişim Kolaylığ1 } & C6.1 & 0,623 & 0,600 & 0,655 & 0,667 & 0,667 & 0,600 & 0,655 & 0,643 & 0,574 & 0,655 \\
\hline & C6.2 & 0,377 & 0,400 & 0,345 & 0,333 & 0,333 & 0,400 & 0,345 & 0,357 & 0,426 & 0,345 \\
\hline \multirow{3}{*}{$\begin{array}{c}\text { Banka } \\
\text { İmaj1/İtibarı }\end{array}$} & C7.1 & 0,468 & 0,229 & 0,505 & 0,545 & 0,531 & 0,467 & 0,457 & 0,474 & 0,450 & 0,154 \\
\hline & C7.2 & 0,208 & 0,343 & 0,198 & 0,287 & 0,174 & 0,311 & 0,217 & 0,211 & 0,204 & 0,292 \\
\hline & C7.3 & 0,323 & 0,429 & 0,297 & 0,169 & 0,295 & 0,222 & 0,326 & 0,316 & 0,346 & 0,555 \\
\hline \multirow{4}{*}{ Kuruma Bağlılık } & $\mathrm{C} 8.1$ & 0,443 & 0,377 & 0,439 & 0,517 & 0,499 & 0,406 & 0,403 & 0,496 & 0,398 & 0,503 \\
\hline & $\mathrm{C} 8.2$ & 0,269 & 0,290 & 0,183 & 0,272 & 0,250 & 0,194 & 0,310 & 0,268 & 0,306 & 0,265 \\
\hline & $\mathrm{C} 8.3$ & 0,179 & 0,162 & 0,274 & 0,076 & 0,131 & 0,129 & 0,172 & 0,138 & 0,170 & 0,139 \\
\hline & $\mathrm{C} 8.4$ & 0,109 & 0,171 & 0,104 & 0,136 & 0,119 & 0,271 & 0,115 & 0,098 & 0,126 & 0,093 \\
\hline
\end{tabular}


Ek 9. Bütünleşik Nihai Kriter Ağırlıkları ve Kriter Sıralamaları

\begin{tabular}{|c|c|c|c|c|c|c|c|c|c|c|c|c|c|c|}
\hline & Alt Kriterler & KV1 & KV2 & KV3 & KV 4 & KV5 & KV6 & KV7 & KV8 & KV9 & KV10 & $\begin{array}{l}\text { Geo. } \\
\text { Ort. }\end{array}$ & $\begin{array}{c}\text { Bütünleşik Nihai } \\
\text { Kriter Ağırlığı }\end{array}$ & Siralama \\
\hline \multirow[t]{3}{*}{$\mathrm{C} 1$} & C1.1 Bankanın finansal gücü & 0,053 & 0,026 & 0,008 & 0,020 & 0,084 & 0,032 & 0,019 & 0,008 & 0,008 & 0,011 & 0,019 & 0,028 & 14 \\
\hline & $\begin{array}{l}\text { C1.2 Bankanın iç-dış } \\
\text { görünümü }\end{array}$ & 0,031 & 0,022 & 0,002 & 0,005 & 0,127 & 0,016 & 0,005 & 0,002 & 0,002 & 0,006 & 0,009 & 0,012 & 21 \\
\hline & $\begin{array}{l}\text { C1.3 Bankanın teknolojik } \\
\text { altyapıs1 }\end{array}$ & 0,040 & 0,039 & 0,004 & 0,010 & 0,253 & 0,023 & 0,010 & 0,004 & 0,004 & 0,021 & 0,016 & 0,023 & 16 \\
\hline \multirow[t]{4}{*}{$\mathrm{C} 2$} & $\begin{array}{l}\text { C2.1 Personeli bilgili ve } \\
\text { konusuna vakıf olması }\end{array}$ & 0,026 & 0,016 & 0,009 & 0,004 & 0,000 & 0,026 & 0,051 & 0,007 & 0,009 & 0,000 & 0,007 & 0,010 & 25 \\
\hline & \begin{tabular}{|l|} 
C2.2 Personelin işlemleri hızlı \\
ve doğru sonuçlandırması
\end{tabular} & 0,017 & 0,018 & 0,013 & 0,002 & 0,003 & 0,036 & 0,046 & 0,012 & 0,003 & 0,001 & 0,008 & 0,012 & 23 \\
\hline & $\begin{array}{l}\text { C2.3 Personelin yol gösterici } \\
\text { ve yardımsever olması }\end{array}$ & 0,007 & 0,011 & 0,020 & 0,001 & 0,001 & 0,018 & 0,029 & 0,004 & 0,005 & 0,003 & 0,006 & 0,009 & 26 \\
\hline & \begin{tabular}{|l} 
C2.4 Personelin iyi müşteri \\
ilişkileri ve bağlantıları
\end{tabular} & 0,011 & 0,010 & 0,030 & 0,001 & 0,001 & 0,013 & 0,018 & 0,003 & 0,002 & 0,002 & 0,005 & 0,006 & 28 \\
\hline \multirow[t]{4}{*}{$\mathrm{C} 3$} & $\begin{array}{l}\text { C3.1 Kredi kullanma } \\
\text { kolaylığ1 }\end{array}$ & 0,034 & 0,034 & 0,076 & 0,211 & 0,005 & 0,048 & 0,057 & 0,159 & 0,099 & 0,019 & 0,048 & 0,068 & 4 \\
\hline & $\begin{array}{l}\text { C3.2 Bürokratik işlemlerin az } \\
\text { olması }\end{array}$ & 0,051 & 0,025 & 0,021 & 0,062 & 0,002 & 0,109 & 0,086 & 0,055 & 0,040 & 0,010 & 0,030 & 0,042 & 10 \\
\hline & $\begin{array}{l}\text { C3.3 Yapılan işlemlerden } \\
\text { düşük masraf alınması }\end{array}$ & 0,079 & 0,040 & 0,039 & 0,117 & 0,003 & 0,072 & 0,163 & 0,096 & 0,052 & 0,035 & 0,050 & 0,071 & 3 \\
\hline & $\begin{array}{l}\text { C3.4 Verilen faizin yüksek } \\
\text { olmas1 }\end{array}$ & 0,023 & 0,023 & 0,011 & 0,041 & 0,001 & 0,034 & 0,030 & 0,031 & 0,033 & 0,009 & 0,017 & 0,025 & 15 \\
\hline \multirow[t]{4}{*}{$\mathrm{C} 4$} & $\begin{array}{l}\text { C4.1 Kredi olanaklarının } \\
\text { çeşitliliği }\end{array}$ & 0,015 & 0,010 & 0,021 & 0,002 & 0,010 & 0,008 & 0,034 & 0,052 & 0,011 & 0,006 & 0,012 & 0,017 & 19 \\
\hline & C4.2 çek defteri vermesi & 0,022 & 0,008 & 0,007 & 0,001 & 0,002 & 0,011 & 0,019 & 0,009 & 0,004 & 0,003 & 0,006 & 0,009 & 27 \\
\hline & $\begin{array}{l}\text { C4.3 finansal danışmanlık } \\
\text { hizmeti sağlanması }\end{array}$ & 0,034 & 0,015 & 0,013 & 0,001 & 0,005 & 0,015 & 0,011 & 0,018 & 0,013 & 0,010 & 0,010 & 0,014 & 20 \\
\hline & \begin{tabular}{|l} 
C4.4 Değişen pazar \\
ihtiyaçlarına yönelik yeni \\
ürünlerin sunulamaması
\end{tabular} & 0,009 & 0,007 & 0,004 & 0,000 & 0,003 & 0,006 & 0,006 & 0,029 & 0,006 & 0,002 & 0,004 & 0,006 & 29 \\
\hline \multirow[t]{5}{*}{ C5 } & $\begin{array}{l}\text { C5.1 Kişisel bilgilerin } \\
\text { saklanması }\end{array}$ & 0,097 & 0,057 & 0,052 & 0,141 & 0,004 & 0,007 & 0,114 & 0,052 & 0,136 & 0,064 & 0,047 & 0,066 & 5 \\
\hline & \begin{tabular}{|l|} 
C5.2 Bankanın uzun \\
zamanadır faaliyette \\
bulunması
\end{tabular} & 0,039 & 0,044 & 0,092 & 0,023 & 0,010 & 0,014 & 0,040 & 0,086 & 0,068 & 0,121 & 0,041 & 0,058 & 8 \\
\hline & $\begin{array}{l}\text { C5.3 Bankanın tavsiye } \\
\text { edilmesi }\end{array}$ & 0,028 & 0,031 & 0,028 & 0,041 & 0,005 & 0,009 & 0,060 & 0,009 & 0,038 & 0,035 & 0,023 & 0,032 & 13 \\
\hline & C5.4Devlet bankası olmas1 & 0,061 & 0,022 & 0,165 & 0,070 & 0,019 & 0,021 & 0,029 & 0,017 & 0,142 & 0,231 & 0,050 & 0,071 & 2 \\
\hline & $\begin{array}{l}\text { C5.5 Sürekli hatalı işlemlerle } \\
\text { karşılaşılması }\end{array}$ & 0,017 & 0,066 & 0,015 & 0,011 & 0,002 & 0,005 & 0,015 & 0,030 & 0,019 & 0,020 & 0,014 & 0,020 & 18 \\
\hline \multirow[t]{2}{*}{ C6 } & $\begin{array}{l}\text { C6.1 Bankanın uygun } \\
\text { yerleşim yeri }\end{array}$ & 0,097 & 0,088 & 0,080 & 0,096 & 0,053 & 0,078 & 0,055 & 0,137 & 0,034 & 0,162 & 0,080 & 0,114 & 1 \\
\hline & \begin{tabular}{|l|} 
C6.2 Bankanın üst düzey \\
yöneticilerine ulaşma zorluğu
\end{tabular} & 0,059 & 0,058 & 0,042 & 0,048 & 0,027 & 0,052 & 0,029 & 0,076 & 0,025 & 0,085 & 0,046 & 0,066 & 6 \\
\hline \multirow[t]{3}{*}{$\overline{\mathrm{C} 7}$} & C7.1 Bankanın tanınmışlığı & 0,049 & 0,060 & 0,111 & 0,010 & 0,072 & 0,073 & 0,021 & 0,029 & 0,067 & 0,020 & 0,041 & 0,059 & 7 \\
\hline & C7.2 Çevre dostu olması & 0,022 & 0,090 & 0,044 & 0,005 & 0,024 & 0,049 & 0,010 & 0,013 & 0,030 & 0,038 & 0,024 & 0,035 & 12 \\
\hline & $\begin{array}{l}\text { C7.3 Bankanın toplumsal } \\
\text { konulara hassasiyeti }\end{array}$ & 0,033 & 0,113 & 0,065 & 0,003 & 0,040 & 0,035 & 0,015 & 0,019 & 0,052 & 0,072 & 0,032 & 0,046 & 9 \\
\hline \multirow[t]{4}{*}{$\mathrm{C} 8$} & \begin{tabular}{|l|} 
C8.1 Bankanın sunduğu \\
hizmet kalitesinin sürekliliği
\end{tabular} & 0,021 & 0,025 & 0,011 & 0,037 & 0,122 & 0,077 & 0,012 & 0,021 & 0,040 & 0,006 & 0,026 & 0,037 & 11 \\
\hline & $\begin{array}{l}\text { C8.2 Bankanın müşsterilerine } \\
\text { kişisel ilgi göstermesi }\end{array}$ & 0,013 & 0,019 & 0,005 & 0,020 & 0,061 & 0,036 & 0,009 & 0,011 & 0,030 & 0,003 & 0,015 & 0,021 & 17 \\
\hline & $\begin{array}{l}\text { C8.3 Katılım (faizsiz) bankas1 } \\
\text { olmas1 }\end{array}$ & 0,008 & 0,011 & 0,007 & 0,005 & 0,032 & 0,024 & 0,005 & 0,006 & 0,017 & 0,002 & 0,009 & 0,012 & 22 \\
\hline & $\begin{array}{l}\text { C8.4 Personelin eş dost, } \\
\text { tanıdık, akraba olması }\end{array}$ & 0,005 & 0,011 & 0,003 & 0,010 & 0,029 & 0,051 & 0,003 & 0,004 & 0,013 & 0,001 & 0,007 & 0,010 & 24 \\
\hline
\end{tabular}


Ek 10. Bütünleşik Karar Matrisi

\begin{tabular}{|c|c|c|c|c|c|c|c|c|c|c|c|c|c|c|c|c|c|c|c|c|c|c|c|c|c|c|c|c|c|}
\hline & & & & & & & & & & 3.3 & & & & & \begin{tabular}{|c|c|} 
\\
\end{tabular} & & & 5.3 & C5.4 & C5.5 & 6.1 & C6.2 & \begin{tabular}{|l|l|} 
& C7.1
\end{tabular} & C7.2 & C7.3 & C8.1 & C8.2 & C.3. & \\
\hline $\mathbf{M}$ & & 5 & & & & & & & 768 & & & & & & & & & & & 37,810 & & & 040 & & 43,154 & 0,71 & & & \\
\hline 12 & & & & & & & & & & & & & & & & & & & & & & & & & & & & & \\
\hline A3 & & & & & & & & & & & & & & & & & & & & & & & & & & & & & \\
\hline $\mathbf{1 4}$ & & & & & & & & & & & & & & & & & & & & & & & & & 736 & & & & \\
\hline 15 & & & & & & & & & & & & & & & & & & & & & & & & & & & & & \\
\hline A6 & & & & & & & & & & & & & & & & 47,182 & & & & & & & & & & & & & \\
\hline & & & & & & & & & & 163 & & & & & & 52,12 & & & & & 3 & & & & & & & & \\
\hline 18 & & & & & & & & & & & & & & & & & & & & & & & & & & & & & \\
\hline & & & & & & & & & & & & & & & & & & & & & & & & & & & & & \\
\hline & 32,660 & 4 & & & & & & & & & & & & & & & & & & & & & & & & (77,2 & & & \\
\hline & 36,120 & 128 & 520 & 244 & 186 & 37,340 & 50,170 & 50,090 & \begin{tabular}{|l|l|l|} 
&
\end{tabular} & 502 & 54,234 & {$[55,356$} & $|38,960|$ & $|39,770|$ & & 43,227 & $|49,440|$ & $|30,920|$ & 0 & 339 & 45,69 & $|37,690|$ & $|58,300|$ & & 29,926 & 541,76 & 52,7 & 99,3 & \\
\hline & 76,930 & 272 & & & & 67,760 & 72. & & & & & & & 66,020 & & & & $\mid 79,690$ & & & 69,740 & 00 & 95,210 & & & 77,0 & & & \\
\hline 13 & 68,280 & 68,477 & 470 & & & 550 & 63,290 & & 51,625 & & & & 43, & 63,810 & & & & $|72,270|$ & & & $3 \mid 63,200$ & $|31,570|$ & $84,470 \mid$ & & & $\begin{array}{l}9 \mid 77,7 \\
\end{array}$ & & & \\
\hline 14 & 75,080 & 76,062 & & & 555 & , 190, & 69,790 & & & & & & 570 & $|54,770|$ & & 373 & & $|72,480|$ & & & 360 & 900 & 89,920 & & & 6,75 & & & \\
\hline & 83,040 & 75,485 & & & & & 65,040 & & & & & & 46,570 & & & & & 85,580 & & & & & 94,270 & & & 71,5 & & & \\
\hline & \begin{tabular}{|l|l|}
58,820 \\
\end{tabular} & \begin{tabular}{|c|}
60,481 \\
\end{tabular} & & \begin{tabular}{|l|l|} 
& 60,3
\end{tabular} & & & 58, & & & & & & & & & & & & & & & & & & & & & & \\
\hline & 80 & 45 & 680 & \begin{tabular}{|l}
54,065 \\
\end{tabular} & 8,109 & 46,800 & , & $|42,280|$ & \begin{tabular}{|l|l|}
48,790 \\
\end{tabular} & 46,360 & \begin{tabular}{|l|l|}
44,094 \\
\end{tabular} & $|56,890|$ & |40,850 & 57,4 & 43,88 & 54,463 & $59,61 \mathrm{C}$ & $\mid 56,320$ & 39,860 & 24,526 & 59,02 & 33,32 & 73,360 & 37,880 & 38,713 & & & 9,0 & \\
\hline
\end{tabular}

\section{Ek 11. Normalize Karar Matrisi}

\begin{tabular}{|c|c|c|c|c|c|c|c|c|c|c|c|c|c|c|c|c|c|c|c|c|c|c|c|c|c|c|c|c|c|}
\hline & & $\mathbf{K}$ & & & $\mathrm{K}$ & AK & MAK & MAK & MAK & AK & & $\mathbf{A K}$ & $\mathbf{~} \mathbf{K}$ & MAK & Min & MAK & $\mathbf{A K}$ & $\mathbf{A K}$ & $\mathbf{A K}$ & in & $\mathbf{A K}$ & MiN & $\mathrm{AK}$ & MAK & IAK & IAK & IAK & MAK & \\
\hline & & & & & & & & & & & & & & & & & & & & 8.5 & 5.1 & 6.2 & 7.1 & 7.2 & 7.3 & 8.1 & 8.2 & 8.3 & \\
\hline & & & & & & & & & & & & & & & & & & & & & & & & & & & 52 & & to, \\
\hline & & & & & & & & & & & & & & & & & & & & & & & & & & & & & 126 \\
\hline & & & & & & & & & & & & & & & & & & & & & & & & & & & 09 &,, 26 & 131 \\
\hline & & & & & & & & & & & 268 & & & & & & & & & 48 & 166 & 35 & & 10 & 190 & 152 & 209 & 0,235 & 0,208 \\
\hline & & & & & & & & & & & & & & & & & & & & & & & & & & & & & {$[0,29$.} \\
\hline & & & & & & & & & & & & & & & & & & & & & & & & & & & & & 22 \\
\hline & & & & & & & & & & & & & & & & & & & & & & & & & & & 23 & {$[0,2$} & $\mid 0,263$ \\
\hline & & & & & & & & & & & & & & & & & & & & & 127 & & & & & 0,16 & 201 & 0,2 & 0,144 \\
\hline & & & & & & & & & & & & & & & & & & & & & & & & & & 220 & 22 & & 22 \\
\hline & & & & & & & & & & & & & & & & & & & & & & & & & & 200 & 20 & & 0,243 \\
\hline & & & & & & & & & & & & & & & & & & & & & & & & & & 177 | & 20 & & 0,209 \\
\hline & & & & & & & & & & & & & & & & & & & & & 351 & & & & & 0,32 & 0,300 & 0,25 & 0,315 \\
\hline & & & & & & & & & & & & & & & & & & & & & & & & & & & & & 0,286 \\
\hline & 0,355 & & & & & & & & & & & & & & & & & & & & & & & & & 2833 & 262 & {$[0,233$} & 0,319 \\
\hline & 0, & & & & & & & & & & & & 90 & 90 & & 93 & & & & 80 & 343 & 79 & 348 & 28 & 347 & 303 & 0,288 & 0,232 & 0,310 \\
\hline & & & & & & & & & & & & & & & & & & & & & & & & & & 272 & 41 & & 0,278 \\
\hline & & & & & & & & & & & & & & & & & & & & & & & & & & & & & \\
\hline
\end{tabular}

\section{Ek 12. MOORA - Oran Metoduna Göre Siralama}

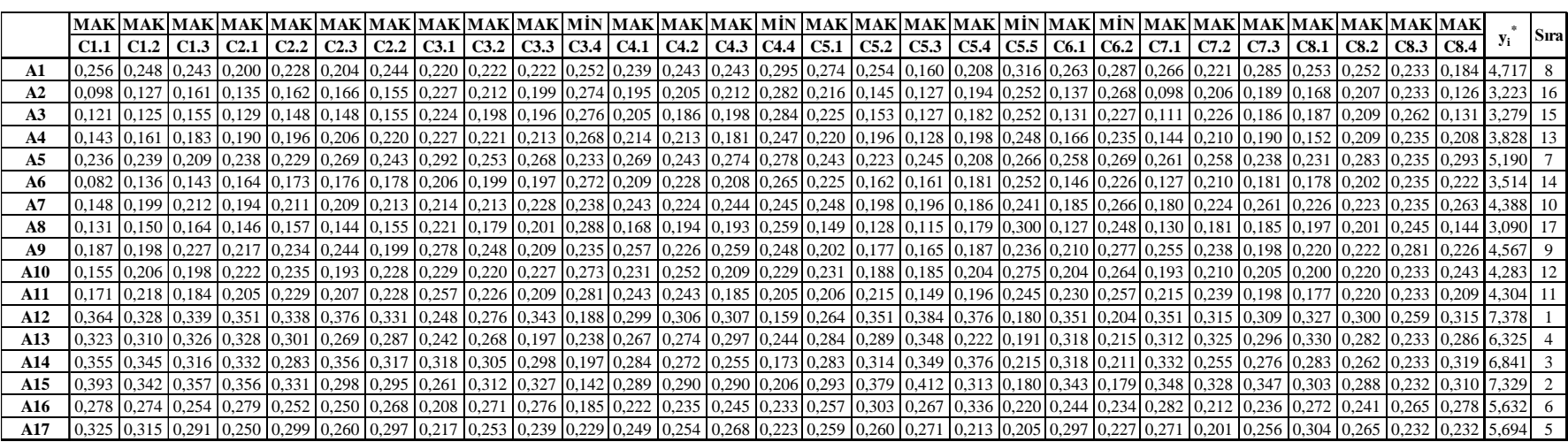




\section{Ek 13. MOORA - Referans Noktası Yaklaşımına Göre Sıralama}

\begin{tabular}{|c|c|c|c|c|c|c|c|c|c|c|c|c|c|c|c|c|c|c|c|c|c|c|c|c|c|c|c|c|c|c|c|}
\hline & & & & & & & & & & & & & & & & & $\mathbf{K}$ & & & & $\mathbf{A} \mathbf{1}$ & & & & 1 & & & & & & \\
\hline & \begin{tabular}{|l|l|} 
C1.1 \\
\end{tabular} & & & & & & & & & & & & 1.2 & 4.3 & & & C5.2 & 5.3 & & .5 & \begin{tabular}{|l|} 
C6.1 \\
\end{tabular} & 6.2 & \begin{tabular}{l|l}
7.1 & $\mathrm{C}$
\end{tabular} & & C7.3 & 8.1 & 8.2 & C8.3 & C8.4 & & \\
\hline & 37 & 97 & & & & & & & & & & & & 64 & & & & & & & 888 & 107 & & & $\mid 0,061$ & 077 & 14 & 0.04 & 13 & & \\
\hline & & & & & & & & & & & & & & & & & & & & & & & & & & & & & & & \\
\hline & & & & & & & & & & & & & & & & & & & & & & & & & & & & & & & \\
\hline & & & & & & & & & & & & & & & & & & & & & & & & & & & & & & & \\
\hline & & & & & & & & & & & & & & & & & & & & & & & & & & & & & & & \\
\hline & & & & & & & & & & & & & & & & & & & & & & & & & & & & & & & \\
\hline & & & & & & & & & & & & & & & & & & & & & & & & & & & & & & & \\
\hline & & & & & & & & & & & & & & & & & & & & & & & & & & & & & & & \\
\hline & & & & & & & & & & & & & & & & & & & & & & & & & $t$ & & & & & & \\
\hline & & & & & & & & & & & & & & & & & & & & & & & & & & & & & & & \\
\hline & & & & & & & & & & & & & & & & & & & & & & & & & 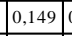 & & & & 4 & 263 & \\
\hline & & & & & & & & & & & & & & 0,000 & & & & & & & 0,000 & & & & {$[0,0$} & & & & & & \\
\hline & & & & & & & & & & & & & & & & & & & & & & & & & & & & & & & \\
\hline & & & & & & & & & & & & & & & & & & & & & & & & & & & & & & & \\
\hline & & 03 & & & & & & & 0,000 & & & & \begin{tabular}{|l|l|} 
\\
\end{tabular} & 0,017 & 0, & & 000 & & & & 0,008 & & \begin{tabular}{l|l}
03 & 0 \\
\end{tabular} & 000 & 0,000 & 027 & & & & 178 & \\
\hline & (0,115 & \begin{tabular}{|l|l|}
0,071 \\
\end{tabular} & \begin{tabular}{|l|l|}
0,103 \\
\end{tabular} & \begin{tabular}{|l|l|}
0,076 \\
\end{tabular} & 0,086 & \begin{tabular}{|l|}
0,126 \\
\end{tabular} & 0,064 & 0,110 & \begin{tabular}{|l|l|} 
\\
\end{tabular} & \begin{tabular}{|l|}
0,067 \\
\end{tabular} & 0,043 & 0,077 & \begin{tabular}{|c|}
0,071 \\
\end{tabular} & \begin{tabular}{|l|l|}
0,062 \\
\end{tabular} & \begin{tabular}{|l|l|}
0,075 \\
\end{tabular} & & 0,076 & $|0,145|$ & 440 & & 0,106 & 0,055 & {$[0,070 \mid 0$} & $\begin{array}{ll}5 \\
\end{array}$ & 0,111 & 058 & $\begin{array}{l}8 \\
\end{array}$ & {$[0,0$} & {$[0,041$} & 0,145 & \\
\hline & {$[0,001]$} & 03 & , & {$[0,105$} & & 0,11 & & {$[0,101]$} & {$[0,059]$} & $|0,104|$ & 0,086 & 0,050 & 0,052 & 0,04 & 0,06 & & $\mid 0,119$ & $\mid 0,141$ & {$[0,162]$} & {$[0,025]$} & $\mid 0,05$ & 0,04 & 0,08 & {$[0,127]$} & {$[0,09$} & 0,02 & {$[0,036]$} & & & 16 & \\
\hline
\end{tabular}

Ek 14. MOORA - Tam Çarpım Formu Yaklaşımına Göre Sıralama

\begin{tabular}{|c|c|c|c|c|c|c|c|c|c|c|c|c|c|c|c|c|c|c|c|c|c|c|c|c|c|c|c|c|c|c|c|c|c|}
\hline & & & & & & & & & & & & & & & & & & & & & IAK & & $\mathbf{~} \mathbf{K}$ & & & & & & & & & & \\
\hline & & & 3 & & & & & 1.1 & & 3 & $\begin{array}{c}\mathrm{c} .4 .4 \\
\end{array}$ & & 4.2 & C4.3 & & \begin{tabular}{c|c|} 
c5.1 \\
\end{tabular} & .2 & 5.3 & \begin{tabular}{ll|}
$\mathrm{C} 5.4$ \\
\end{tabular} & 5.5 & \begin{tabular}{|l|l|}
$\mathrm{C} 6.1$ \\
\end{tabular} & \begin{tabular}{ll|}
6.2 \\
\end{tabular} & 7.1. & $\begin{array}{ll}\mathrm{C} 7.2 \\
\end{array}$ & \begin{tabular}{|l|c|c|}
2 & $\mathrm{C} 7.3$ \\
\end{tabular} & 8.1 & \begin{tabular}{ll|} 
c8. \\
\end{tabular} & 8.3 & $c 8.4$ & & & & \\
\hline & & & 0,243 & & & 204 & & 20 & & & 0,252 & & 243 & 0,243 & & 274 & \begin{tabular}{|l|l|} 
\\
\end{tabular} & 160 & 0,208 . & 16 & 0,263 & 0.287 & 266 & 0,21 & 0,285 & 0,253 & 0,252 & 0.233 & 0,184 & 0,000 & 0,007 & 0,000 & \\
\hline & & & & & & & & & & & & & & & & & & & & & 137 & 0,268 & & .206 & 0,189 & 168 & 0,207 & & & 1000 & 1003 & 00 & \\
\hline & & & & & & & & & & & & & & & & & & & & & & & 11 & & & 187 & 209 & To & 0,131 & 0,000 &, 004 &, 00 & \\
\hline & & & & & & & & & & & & & & & & \begin{tabular}{|l|l|}
0,220 \\
\end{tabular} & & & & & & & & & & & & & & & & & \\
\hline A5 & & & & & & & & & & & & & & & & & & & & & & & & & & & & & & & & & \\
\hline & & & & & & & & & & & & & & & & & & & & & & & & & & & & & & & & & \\
\hline & & & & & & & & & & & & & & & &, 248 & & 96 & & 241 & 185 & & 80 & & 261 & 226 & .223 & & ]$^{0,263}$ & 0,000 & 004 &, 00 & \\
\hline & & & & & & 0. & & & & & & & & & & .149 & & & & 00 & & & & & & & 201 & & 0,144 & 0,000 & 006 & 0.00 & \\
\hline & & & & & & & & & & & & & & & & \begin{tabular}{|l|l|}
0,202 \\
\end{tabular} & & & & & & & & 238 & & & 22 & & & & & & \\
\hline & & & & & & & & & & & & & & & & \begin{tabular}{|l|l|}
0,231 \\
\end{tabular} & 88 & & & 275 & & & 193 & & 0,205 & \begin{tabular}{|l|l|} 
\\
\end{tabular} & ${ }^{20}$ & & & & & & \\
\hline & & & & & & & & & & & & & & & & & & & & & & & & & & & & & & & & & \\
\hline & & & & & & & & & & & & & & & & \begin{tabular}{|l|l|}
0,264 \\
\end{tabular} & & & & & & & & & & & & & & & & & \\
\hline & 0,323 & 1,310 & 0,3 & & 01 & 0, & & 42 & & & & & \begin{tabular}{|l|l|}
0.274 \\
\end{tabular} & & & \begin{tabular}{|l|l|}
0,284 \\
\end{tabular} & & 348 & & 191 & 0,318 & & 312 & 0,325 & 0,296 & 0,330 & 282 & 0,233 & 0,286 & 0,000 & 002 & 0000 & \\
\hline 14 & 0,355 & 0.345 & \begin{tabular}{|l|l|} 
\\
\end{tabular} & & \begin{tabular}{|l}
0,283 \\
\end{tabular} & 0,356 & & \begin{tabular}{|l|}
0,318 \\
\end{tabular} & 3055 & 298 & \begin{tabular}{|l|l|}
0,197 \\
\end{tabular} & 0,284 & $0,2,22$ & 0,255 & 0,1 & \begin{tabular}{|l|l|}
0,283 \\
\end{tabular} & \begin{tabular}{|l|l|}
0,314 \\
\end{tabular} & 0,349 & 0,376 & 0,215 & 0,318 & 0,211 & 0,332 & 0,255 & \begin{tabular}{|l|l|}
5 & 0,276 \\
\end{tabular} & 0,283 & 0,262 & \begin{tabular}{|l|l|}
0,233 \\
\end{tabular} & {$[0,19$} & 0,000 & .002 & 000 & \\
\hline & & & & & & & & & & & & & & & & & 79 & & & & & & & & & & & & & & & & \\
\hline & & & 0.2 & & & & & & & & & & & & & & & & & & & & & & & & & & & & & & \\
\hline & 0.325 & 0.315 & \begin{tabular}{|l|l|}
0.291 \\
\end{tabular} & $0,0,250$ & \begin{tabular}{|l|l|}
0,299 \\
\end{tabular} & 0,260 & $0,0,297$ & \begin{tabular}{|l|l|}
0,217 \\
\end{tabular} & 0,253 & 0,239 & 0,229 & \begin{tabular}{|l|l|}
0,249 \\
\end{tabular} & 0,254 & 0,268 & \begin{tabular}{|l|l|} 
\\
\end{tabular} & \begin{tabular}{|l|}
0,259 \\
\end{tabular} & 0,260 & 0,271 & 0,213 & \begin{tabular}{|l|l|} 
\\
\end{tabular} & \begin{tabular}{|l|l|}
0,297 \\
\end{tabular} & 0.227 & \begin{tabular}{|l|l|}
0,271 \\
\end{tabular} & 0,201 & \begin{tabular}{|l|l|}
1 & 0,256
\end{tabular} & $0,0,304$ & 0,265 & 0,232 & 0,232 & 0,000 & 0,002 & & \\
\hline
\end{tabular}

Ek 15. MOORA - Önem Katsayısı Yaklaşımına Göre Sıralama

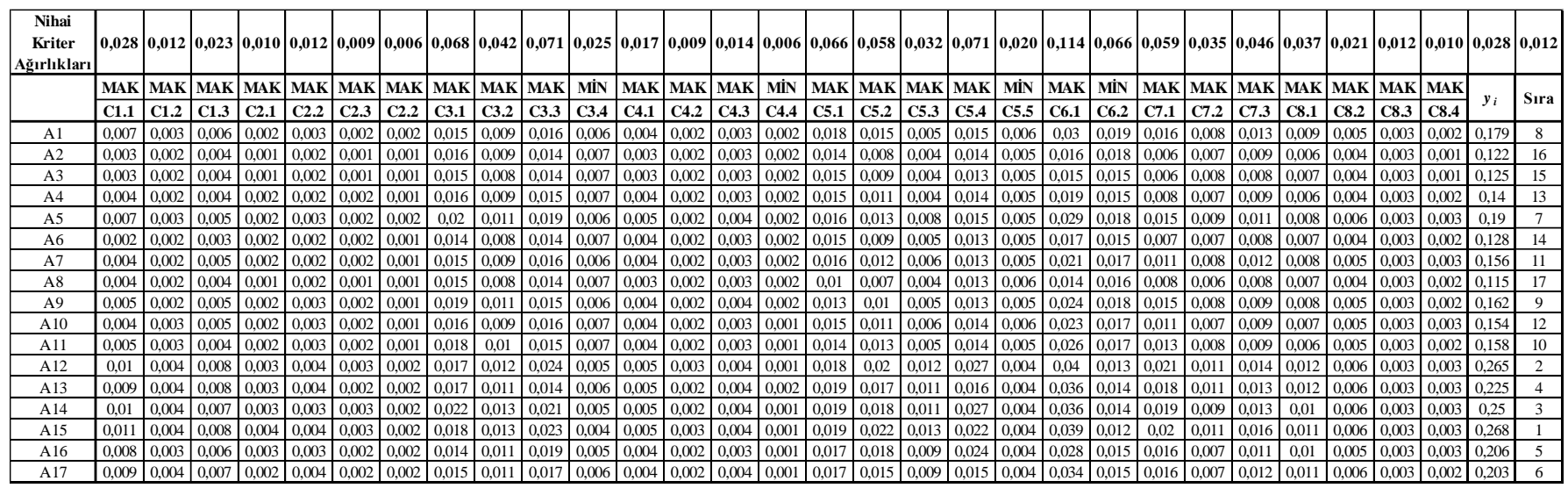


Ek 16. Kriter Ağırlıklı Referans Noktası Yaklaşımına Göre Sıralama

\begin{tabular}{|c|c|c|c|c|c|c|c|c|c|c|c|c|c|c|c|c|c|c|c|c|c|c|c|c|c|c|c|c|c|c|c|}
\hline & & & & & & & & & & & & & & & & & & & & iiv & & III & & & & & & & & & \\
\hline & \begin{tabular}{|l|} 
C1.1. \\
\end{tabular} & & & & & & & & .2 & & & \begin{tabular}{|l} 
C4.1. \\
\end{tabular} & 1.2 & & & 5.1 & & & & & & & 7.1 & .2 & & $\begin{array}{ll}\text { C8.1 } \\
\end{array}$ & & & & & \\
\hline & & & & & & & & & & & & & & & & & & & & & & & & & & & & & & 012 & \\
\hline & & & & & & & & & & & & & & & & & & & & & & & & & & & & & & & \\
\hline & & & & & & & & & & & & & & & & & & & & & & & & & & & & & & & \\
\hline & & & & & & & & & & & & & & & & & & & & & & & & & & \begin{tabular}{|l|}
0,007 \\
\end{tabular} & 002 & & 0,001 & & \\
\hline & & & & & & & & & & & & & & & & & & & & & & & & & & & & & & & \\
\hline & & & & & & & & & & & & & & & & & & & & & & & & & & & & & & & \\
\hline & & & & & & & & & & (008 & & & 001 & & & \begin{tabular}{l|l}
003 & 0
\end{tabular} & & & & & & 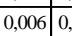 & & & & \begin{tabular}{|l|l|}
0,004 \\
\end{tabular} & 0,002 & & 0,001 & 01 & \\
\hline & & & & & & & & & & & & & & & & & & & & & & & & & & & & & & & \\
\hline & & & & & & & & & & & & & & & & & & & & & & & & & & & & & & & \\
\hline & & & & & & & & & & & & & & & & & & & & & & & & & & & & & & & \\
\hline & & & & & & & & & & & & & & & & & & & & & & & & & & & & & & 014 & \\
\hline & & & & & & & & & & & & & & & & & & & & & & & & & & & & & & & \\
\hline & & & & & & & & & & & & & & & & & & & & & & & & & & & & & & & \\
\hline & & & & \begin{tabular}{|l|c|}
0,000 \\
\end{tabular} & & 0000 & 000 & \begin{tabular}{|c|c|}
0,000 \\
\end{tabular} & {$[0,000 \mid$} & \begin{tabular}{|l|l|}
0,003 & \\
\end{tabular} & & & & & & & & & & & & & & & & 0,002 & 001 & & &, 004 & \\
\hline & & & & & & & & & & & & & & & & & & & & & & & & & & & & & & & \\
\hline & & & & & & & & & & & & & & & & & & & & & & & & & & & & & & & \\
\hline & \begin{tabular}{|l|}
0,002 \\
\end{tabular} & \begin{tabular}{|l|l}
0,000 \\
\end{tabular} & {$[0,002]$} & $|0,001| c$ & {$[0,000$} & $0,001 \mid 0$ & $|0,000|$ & | & {$[0,003]$} & {$[0,007] 0$} & {$[0,002]$} & {$[0,001] 0$} & {$[0,000]$} & {$[0,001]$} & {$[0,000]$} & {$[0,002] 0$} & [0,007 & {$[0,005]$} & {$[0,012] 0$} & {$[0,001] 0$} & {$[, 000] 0$,} & $\begin{array}{c}3 \\
\end{array}$ & $0,005] 0$ & {$[0,004] 0$,} & {$[0,004] 0$} & 0,0 & | & & & & \\
\hline
\end{tabular}

